\title{
KARININKAI VYČIO KRYŽIAUS KAVALIERIAI
}

\section{9 - 1926}

Vincas Ruzas

Mūsų istoriografijoje vis daugiau dèmesio skiriama 1918-1940 m. Lietuvos nepriklausomybės aktualijoms. Tyrinejant to meto personalijas iškyla klausimų, susijusių su apdovanojimais ordinais ir medaliais. $2001 \mathrm{~m}$. vasarą buvo išleista žinomo Lietuvos žurnalisto ir kolekcininko Viliaus Kavaliausko knyga "Už nuopelnus Lietuvai. 1918-1940 metų Lietuvos Respublikos ordinai ir medaliai". Ši knyga yra geriausias darbas apie Lietuvos faleristiką. Leidinyje publikuojama iki šiol neskelbta archyvinè medžiaga, taip pat apdovanojimų ženklai, kurie saugomi ne tik Lietuvos, bet ir užsienio muziejuose bei privačiose kolekcijose. Knygos autorius V. Kavaliauskas detaliai išdèste Kryžiaus "Už Tẻvynę" bei Vyties kryžiaus įsteigimo aplinkybes, apžvelgè kai kuriu civilių asmenų bei žymesnių Lietuvos karininku apdovanojimą antrosios rūšies Vyties kryžiumi. Ypač daug dėmesio skirta užsieniečiu apdovanojimo klausimams. V. Kavaliausko duomenimis, pirmosios rūšies Vyties kryžiumi buvo apdovanota žmonių:

1-ojo laipsnio-1396 (1 užsienio pilietis),

2-ojo laipsnio-98,

3-iojo laipsnio-nebuvo apdovanota;

antrosios rūšies Vyties Kryžiumi buvo apdovanota žmonių:

1-ojo laipsnio-78 (iš jų 23 užsieniečiai),

2-ojo laipsnio-22 (Petras Šniukšta ir 21 užsienietis),

3-iojo laipsnio nebuvo apdovanotai.

Šio straipsnio autorius siekia bent iš dalies užpildyti mažiau tirtą karininkų apdovanojimo Vyties kryžiumi temą. Temai atskleisti panaudotas chronologinis principas. Toks principas sudaro galimybę parodyti karininkų apdovanojimą atskirais kovos už nepriklausomybę etapais: ko-

\footnotetext{
* Šis 1920 metų vasario mẻnesi isteigtas apdovanojimas iki 1930 m. buvo vadintas Vyties kryžiumi.-Red. past.

${ }^{1}$ Kavaliauskas V. Už nuopelnus Lietuvai. V. 2001. P. 63, 83
} 
vas prieš bolševikus, bermontininkus, lenkus ir vidaus priešus. Per 19191923 m. laikotarpi pirmosios rūšies 1-ojo laipsnio Vyties kryžiumi buvo apdovanoti 222 karininkai. Labiausiai pasižymèję iš jų 37 karininkai buvo apdovanoti ir 2-ojo laipsnio Vyties kryžiumi. Antrosios rūšies 1-ojo laipsnio Vyties kryžiumi apdovanotas 51 karininkas ir karo valdininkas, o antrosios rūšies 2-ojo laipsnio Vyties kryžiumi buvo apdovanotas vienintelis karininkas-generolas leitenantas Petras Šniukšta.

\section{LIETUVIŠKO APDOVANOJIMO ISTEIGIMAS}

1918 m. vasario 16 d. buvo paskelbta Nepriklausoma Lietuvos valstybè. Reikèjo jègos jai ginti ir saugoti. I karo nualintą, dar vokiečių kariuomenès užimtą kraštą iš Rusijos pradèjo grižť kovose užsigrūdinę lietuviai kariai. Jie savo jëgas paveda pradejjusiai kurtis Lietuvos valdžiai. Iš ju sudaromas kariuomenès branduolys, dèl kurio $1918 \mathrm{~m}$. lapkričio $23 \mathrm{~d}$. buvo išleistas pirmojo krašto apsaugos ministro prof. Augustino Voldemaro oficialus isakymas. Valdžia kvietè savanorius, mobilizavo karininkus, šaukè naujokus, kurie stojo ginti nepriklausomybès. Kuriantis Lietuvos valstybei iš karto teko stoti i kovą su Rusijoje valdžia paèmusiais ir siekusiais ją įtvirtinti buvusioje carineje imperijoje bolševikais.

Kovų su bolševikais metu imta galvoti apie pasižymejjusių karių apdovanojimus. Kol tokio ženklo nebuvo, vadai reikšdavo padèkas bendražygių akivaizdoje. Vyriausybė, atlikdama organizacinius valstybès kuriamuosius darbus, neturejjo laiko karių apdovanojimo ženklui kurti. Iniciatyvos ėmėsi pirmasis kariuomenès vadas generolas Silvestras Žukauskas. Jis 1919 m. gegužès 18 d. išleido issakymą Nr. 6, kuriame paskelbè: "Ateityje viršininkai veikiančiu kariuomenès dalių turi pristatinèti man per savo tiesioginius viršininkus kaip karininkus taip ir kareivius atsižymëjusius mūšyje dèl apdovanojimo ordinu, iki išleidimui kurio bus išduodamos nešiojimui sagos kilpelèje ordino kaspinèlis, šiuos pristatymus man užtvirtinus". Pirmieji raportai su pasižymëjusių karių sąrašais vyriausiajam karo vadui gen. S. Žukauskui buvo perduoti 1919 metų birželio mènesị. Gen. S. Žukauskas peržiūrèdavo sąrašus, juos patvirtindavo, vykdavo i frontą ir pasižymejjusiems kariams pats prisegdavo kaspinèlius. Po to trumpa kalba kreipdavosi i kitus karius, pareikšdavo viltị, kad po kitu 
kautynių turès laimę ir jie būti apdovanoti. Apdovanotujų sąrašai buvo skelbiami dalių isakymuose ${ }^{2}$. Tokia buvo lietuvišku apdovanojimų užuomazga. Atkurti vieną apdovanojimo epizodą padeda Panevėžio bataliono vyr. psk. Zarankos atsiminimai.

1919 m. birželio 28 - 29 d. Panevėžio rinktinę aplankė vyriausiasis karo vadas gen. S. Žukauskas, kuris pafrontèje įteikè apdovanojimų kaspinèlius kautynèse pasižymejjusiems karininkams ir kareiviams ${ }^{3}$. Psk. Zaranka rašè, kad netoli Tamosonių kaimo bataliono būrys ant vieškelio, kuris èjo nuo Subatès i Aserno muižę, turèjo laukti vyriausiojo Lietuvos kariuomenès vado generolo Silvestro Žukausko. Nuo Subatès pusès keldamas dulkes atvažiavo automobilis. Kai jis sustojo, iš jo išlipo generolas S. Žukauskas su keliais kitais karininkais. Generolas S. Žukauskas pasisveikino ir pasakè nedidelę kalba, kurioje prašė nepadèti ginklo, kol bolševikai nebus išvyti iš Lietuvos, iškęsti drabužiu, apavo ir maisto trūkumus. "Paskui išdalino Vyties Kryžiaus juosteles visiems atsižymejjusiems kareiviams ir karininkams, nes Vyties Kryžius dar nebuvo padarytas. Paskui jis paprašè, kad mes suriktumèm valio už Prezidentą Smetoną ir Krašto Apsaugos Mnisterį ${ }^{4}$.

1919 m. liepos 30 d. Laikinoji Lietuvos vyriausybė paskelbė pirma pasižymejjusių karių apdovanojimo įstatymą. Pagal šị istatymą buvo ịsteigtas Kryžius "Už Tėvynę". Istatyme nustatyta triju laipsnių kryžius teikti kareiviams ir karininkams už parodytą narsumą kovoje su priešais. Pirmojo ir antrojo laipsnio kryžiai - plieno, trečiojo laipsnio - žalvario. Istatyme pateiktame apdovanojimo aprašyme pažymèta, kad visuose keturiuose kryžiaus kampuose yra užrašas: "už Tẻvynę". Antrojo ir trečiojo laipsniu kryžių kaspinas turi metalini ąžuolo lapu vainiką. Kaspinas nustatytas gegužès 26 d. istatyme. Nusipelniusieji šio apdovanojimo gavo teisę ji nešioti visur ir visada. Kryžiaus "Už Tẻvynę" isstatymą pasirašè Valstybès Prezidentas A.Smetona ir Ministras Pirmininkas M.Sleževičius. Šio isstatymo pabaigoje Kryžius "Už Tẻvynę" i̇vardijamas kaip ordinas - " Ordeno juosta nustatyta įstatymu iš š. m. gegužès mèn. $26 \mathrm{~d} .{ }^{15}$

\footnotetext{
${ }^{2}$ Mjr. Ališauskas. Vyčio Kryžiaus ordinas // Kardas. 1938. Nr. 22. P. 510

${ }^{3}$ Ališauskas K. Kovos dèl Lietuvos nepriklausomybès 1918 - 1920. Čikaga. 1972. T I. P. 265

${ }^{4}$ Vyr. pusk. Zaranka. Mano atsiminimai iš Lietuvos karų // Karys. 1923. Nr. 37. P. 422.

Atsiminimų autorius ne tiksliai apibūdino įteiktas juosteles. Kryžius "Už Tẻvynę"ir Vyties

Kryžius dar nebuvo įsteigti.

${ }^{5}$ Lietuvos kariuomenei ịsakymas Nr. 127. § 1. 1919 rugpjūčio 7 d., Kavaliauskas V. Už nuopelnus Lietuvai. V. 2001. P. 41
} 
Pagal 1919 m. liepos 30 d. ịstatymą ịteisintas Kryžius "Už Tẻvynę" susilaukè kritikos dèl formos. 1919 m. rugpjūčio 8 d. Valstybinè archeologijos komisija nutaré, jog toks Kryžius Lietuvai nebūdingas ir įteikè Ministrų kabinetui raštą, kuriame siūlé įteisinti šešių galu kryžiu iš Vyčio skydo, kaip tinkamiausią lietuviškos simbolikos ir heraldikos formą, gyvavusią Lietuvos Didžiojoje Kunigaikštystèje. Komisijos rašte buvo rašoma: "šiandiena, kai sprendžiama kuriuo būdu papuošti krūtines Tẻvynès gynejjų, kurie su ginklu rankoje kovoja dèl Lietuvos atstatymo, Archeologinè komisija, kariu paakinta ir prašoma, turi garbès kreiptis per p. Švietimo Ministeri i Lietuvos Vyriausybę, kreipdama dèmesi i reikalą pažymèti drąsių karžygiu nuopelnus ne šios dienos ir greitomis sumanytais papuošimais, bet senais ir žilos senovès ženklais, kuriais eidami protèviai sudarė anais laikais galingą valstybę. Istorišku bei tradiciniu atžvilgiu patiektas šešių galų Kryžius-Lietuvos Vyties skydo ženklas visai atatinka, gyvenamam istoriškam momentui ir, tartum, jungia atskirus Lietuvos istorijos laikotarpius ir teikia naujam Valstybès periodui senos milžinų galybès simboli". ${ }^{6}$

Netrukus spaudoje savo nuomonę dèl apdovanojimo pareiškẻ anoniminis autorius "X", tikriausiai vienas iš Valstybinès archeologijos komisijos narių. Jo siūlymas sutampa su šios komisijos pristatytu raštu vyriausybei. 1919 m. rugpjūčio 14 d. "Kariškiu žodyje" minètas autorius rašè "taigi mūsu nuomone tas ženklas turi tam tikru ypatybių: jis turi būti originahs, tautiškas, populeris, turi turèti valstybès reikšmę ir savo išvaizda turèti svarbumo bei rimtumo žymès ... nereikia sekti kitu valstybių ženklu pavyzdžiu...Jei imti kryžių, tai ne paprastą katalikišką, bet kryžiųženklą nuo Vyties skydo"7.

Tačiau turèjo praeiti tam tikras laiko tarpas, kol Valstybinès archeologijos komisijos siūlymai susilaukè Vyriausybès ir Prezidento pritarimo. Vyriausybè i Valstybinès archeologijos komisijos siūlymą patvirtinti šešiu galų kryžiu iš Vyčio skydo atsižvelgè 1919 m. rugpjūčio 8 d.

1919 m. lapkričio 26 d. Ministru kabineto nutarimu buvo pakeista Kryžiaus forma. Lapkričio 30 d. Prezidentas A.Smetona patvirtino šešiu galų kryžių, bet paliko pavadinimą "Už Tẻvynę". Tačiau $1920 \mathrm{~m}$. vasario 3 d. Prezidento isakymu apdovanojimas buvo pavadintas Vyties kryžiumi.

\footnotetext{
${ }^{6}$ Mjr. Ališauskas. Vyčio Kryžiaus ordinas // Kardas 1938. Nr. 22. P. 510

${ }^{7}$ Kariškių žodis. 1919 rugpjūčio 14 d. Nr. 13. P. 103-104
} 
Vyties kryžius buvo dviejų rūšiu: pirmos - su kalavijais ir antros - be kalavijų. Abiejų rūšių Vyties kryžius buvo trijų laipsnių. Trečiasis laipsnis buvo laikomas aukščiausiu, pirmas-žemiausiu. Kryžiu antroje pusėje buvo numatyta irašyti numeri. Laipsniai žymimi žvaigždutėmis juostelëje ${ }^{8}$.

Apdovanotuju Vyties kryžiumi teisès, pirmenybès, apdovanojimo juo ir jo atemimo tvarka šiame įstatyme nebuvo paliesta. Tai buvo palikta ateičiai. Vis dèlto Vyties kryžius su kalavijais buvo skirtas fronto kariams, o be kalavijų - užnugario darbuotojams apdovanoti.

\section{KOVOSE SU BOLŠEVIKAIS PASIŽYMĖJUSIŲ KARININKŲ APDOVANOJIMAS KRYŽIUMI "UŽ TĖVYNĘ".}

\section{M. RUGPJŪTIS-1919 M. GRUODIS.}

Praejus trims savaitèms po Kryžiaus "Už Tėvynę" issteigimo, 1919 m. rugpjūčio $22 \mathrm{~d}$. Valstybės Prezidento įsakymu už narsumą mūšiuose 1-ojo laipsnio Kryžiumi "Už Tèvynę" buvo apdovanota pirmieji 220 kareivių ir karininkų. Iš 1-ojo pėstininkų pulko 9 karininkai: Petras Murnikas, Jonas Jackus, Vincas Šaudzis, Antanas Žemaitis, Julijonas Čaplikas, Adomas Treideris, Povilas Dundulis, Stasys Marcinkevičius ir Alfredas Šmidtas. Iš 2ojo pėstininku pulko apdovanota 16 karininkų: Emilijus Ginčas, Jonas Laurinaitis, Stasys Puzinas, Kazys Ramanauskas, Augustinas Kynas, Mikas Gaidelis, Jonas Samasionko, Jurgis Butkus, Alfonsas Linkevičius, Kazys Mockevičius, Jonas Kairiunas (turi būti Kairiūnas), Juozas Barkauskas, Antanas Zubrys, Andrius Butkevičius, Jonas Petruitis ir Antanas Budrys. Iš Panevėžio bataliono apdovanota 8 karininkai: Julius Reikalas, Jonas Jurėnas (turi būti Jurènas), Jonas Nastopka, Mikas Obiecanauskis, Aleksandras Žukauskas, Juozas Vidugiris, Mykolas Elisejevas ir Mykolas Kukinas. Iš Baltgudžiu kuopos apdovanota 2 karininkai: Aleksandras Ružancovas ir Steponas Satygo. Iš Artilerijos pulko apdovanota 5 karininkai: Vytautas Kapčiukas, Petras Dočkus, Juozas Giedraitis, Bronius Paškevičius ir Matas Pečiulionis.

Iš viso 1-ojo laipsnio Kryžiumi "Už Tèvynę" apdovanota 40 karininkų.

2-ojo laipsnio Kryžiumi "Už Tėvynę" apdovanoti 3 karininkai: iš 2ojo pesstininku pulko - Antanas Zubrys ir Antanas Budrys, iš Panevėžio bataliono-karininkas Aleksandras Žukauskas.

\footnotetext{
${ }^{8}$ Lietuvos kariuomenei isakymas Nr. 234. §1. 1920 m. vasario 8 d. ; Gaidukaite R. Vyčio Kryžiaus ordinas // Vakarinės naujienos. 1993 m. liepos 7 d. P. 9, Kavaliauskas V. Už nuopelnus Lietuvai. V. 2001. P. 51
} 

kareiviai ${ }^{9}$.

Šio laipsnio Kryžiumi "Už Tèvynę" buvo apdovanoti ir trys

Pirmame apdovanotujų sąraše nėra pirmojo žuvusio už Lietuvos laisvę karininko Antano Juozapavičiaus. Jo žygdarbis buvo ịvertintas 1922 m. Pasižymejjęs ir didvyriškai žuvęs kovoje su bolševikais $1919 \mathrm{~m}$. vasario 13 d. 1-ojo pėstininku didžiojo Lietuvos kunigaikščio Gedimino pulko karininkas Antanas Juozapavičius Lietuvos Prezidento A. Stulginskio 1922 m. gruodžio $8 \mathrm{~d}$. isakymu Nr. 133 buvo apdovanotas pirmosios rūšies 1ojo laipsnio Vyties kryžiumi Nr. $1162^{10}$.

1919 m. rugpjūčio $22 \mathrm{~d}$. Valstybès Prezidento ịsakymu buvo ịteisinti generolo S. Žukausko anksčiau suteikti apdovanojimai. Vèliau pasižymėjusieji kariai buvo apdovanojami tik Respublikos Prezidento isakymais.

Apie Panevėžio bataliono karininkų nuopelnų ịvertinimą Kryžiumi "Už Tèvynę" rašè šio bataliono karininkas Juozas Urbšys. Panevėžio bataliono karininkai pirmiausia pasižymëjo Panevėžio išlaisvinimo operacijoje (1919 m. gegužès 17 d.-23 d.). Iki Panevėžio išvadavimo iš bolševiku Lietuvos kariuomenè savarankiškai didesnių puolimų be vokiečių pagalbos nevykdè. Tai buvo pirmas savarankiškas didelis Lietuvos kariuomenès puolimas. Šioje operacijoje iniciatyvą parodè Panevėžio batalionas ${ }^{11}$.

Kryžiumi "Už Tẻvynę" buvo pagerbtas vienas iš pirmujų žuvusių šioje operacijoje Lietuvos karininku Jonas Nastopkai ${ }^{12}$. Jis žuvo 1919 m. gegužès $18 \mathrm{~d}$. kautynèse prieš bolševikus ties Jeriškiais prie Ramygalos. Kryžių "Už Tèvynę" pakeitus i̇ Vyties kryžiu, už pasižymėjimą kautynėse karininkas Jonas Nastopka buvo apdovanotas 1-ojo laipsnio Vyties kryžiumi su kalavijais Nr. 8. Apdovanojimas vèliau buvo itteiktas jo motinai OlgaiNastopkiene ${ }^{13}$.

${ }^{9}$ Lietuvos kariuomenei įsakymas Nr. 155. § 1.1919 m. rugsèjo 30 d.; Kariškių žodis. 1919. Nr.

31. P. 240

${ }^{10}$ İsakymas kariuomenei Nr. 7. § 2. 1923 m. sausio 9 d.; Karys 1923. Nr. 4. P. 50

${ }^{11}$ Urbšys J. Trumpa Panevėžio bataliono veikimo apžvalga kariaujant $1919 \mathrm{~m}$. su bolševikais

Latvijos teritorijoje // Karys. 1922 m. birželio 3 d. Nr. 22. P. 259

${ }^{12}$ Kariškiu žodis. 1919 Nr. 4. P. 27

${ }^{13}$ Karys. 1929 m. Nr. 26. P. 438-439

105 
Lietuvos daliniams kovojant latvių žemëje Panevėžio bataliono 5 kuopos būrys, birželio 22 d. žvalgydamas issiveržè i Dūkštą. Bolševikams pradejjus pulti, buvo atsitraukta i pirmines pozicijas. Šioje žvalgyboje pasižymėjo Panevėžio bataliono karininkai Jonas Jurènas ir Mikas Obiecanauskas. Šio bataliono vadas Jonas Variakojis, karininkai Aleksandras Žukauskas, Mykolas Elisejevas ir Mykolas Kukinas pasižymëjo liepos 6$12 \mathrm{~d}$. vykusioje operacijoje ${ }^{14}$.

Sumanumą ir kovingumą rodè mūsų artileristai. Karininkas Matas Pečiulionis buvo apdovanotas už atimtus ginklus-patranką ir 7 kulkosvaidžius Anykščių-Kurklių mūšyje gegužès $18 \mathrm{~d}$. M. Pečiulionis šią patranką tuojau panaudojo mūšyje. (Vèliau patranka buvo perduota i Karo muzieju..) $)^{15}$

1919 m. liepos 12 d. vaduojant Salako miesteli pasižymèjo artilerijos pulko karininkas Bronius Paškevičius. Jis priešo apšaudomas sutvarkė telefono ryši ir baterijos ugnimi laiku sustabdè puolanti priešą. Taigi pèstininkai beveik be nuostolių atsikovojo Salako miesteli. Karininkas Bronius Paškevičius už tai pelnè pirmaji savo apdovanojimą ${ }^{16}$.

1919 m. rugpjūčío 22 d. isakymu buvo apdovanota kareivių ir puskarininkių ir iš kitų dalinių: Marijampolès ir Joniškèlio batalionų bei 1ojo raiteliu pulko. Apdovanojimai rodè jaunos besikuriančios Lietuvos kariuomenès pirmus laimėjimus. Karinèse operacijose prieš bolševikus atsiskleide Lietuvos karininkų sugebejimai per trumpą laiką paruošti ir išmokyti karius kovos meno, sumaniai parengti operatyvinius mūšiu planus, kad būtų ịveiktas dažnai daug stipresnis priešas.

1919 m. rugpjūčio 24 d. prasidejo paskutinè operacija prieš bolševikus. 2-ojo pesstininku pulko kpt. E. Noreika su pirmaja ir aštuntaja kuopomis išvijo bolševikus iš Kuklių kaimo ir ịsiveržė i priešo užnugarị. Rugpjūčio 27 d. pirmasis ir trečiasis batalionai kovèsi ties Rautensee dvaru, o antrasis batalionas-ties Gudu kaimu. Puolimo metu ties Rautensee dvaru žuvo karininkas Antanas Sinickis. Rugpjūčio 28 d. pulkas jau kovèsi Latvijos žemėse, o rugpjūčio 30 d. pasiekẻ Kalkūnų dvarą ir stotị.

\footnotetext{
${ }^{14}$ Panevėžio bataliono veikimo aprašymas // Mūsų žinynas. 1920 Nr. 1 P. 94-98

Urbšys J. Trumpa Panevėžio bataliono veikimo apžvalga kariaujant 1919 m. su bolševikais Latvijos teritorijoje // Karys. 1922 m. birželio 3 d. Nr. 22. P. 259

${ }^{15}$ Rudokas J. Prarastieji lietuvos talentai. V 2001. P. 176

${ }^{16}$ Kareivis Lietuvos gynèjas. K. 1926. P. 51
} 
Kautynèse narsūs ir sumanūs buvo šie karininkai: J. Laurinaitis, A. Butkevičius, J. Motiejūnas-Valevičius, K. Butleris, E. Noreika, A. Siniekis, J. Andriūnas, V. Žutautas ir M. Jakobsonas. 1919 m. rugpjūčio 26 d. puolimo Daugpilio fronte metu žuvo 2-ojo pulko 9-osios kuopos vadas. Kuopai vadovauti pradejjus Juozui Andriūnui, kuopa naktị prie Grenzos kaimo puolè bolševikus ir juos sumušè. J. Andriūno vadovaujama kuopa rugpjūčio 28 d. išvijo bolševikus ir iš Neu Šventès bei aplinkinių kaimu ${ }^{17}$.

2-asis pėstininkų pulkas už veiksmus prieš bolševikus gavo vyriausiojo kariuomenès vado generolo S. Žukausko padèkai ${ }^{18}$.

Rugpjūčio 31 d.-rugsėjo 2 d. nepaprastai sunkiai kovota dèl svarbaus strateginio punkto-Kalkūnų stoties, esančios keli kilometrai nuo Daugpilio. Ją atkovojo Lietuvos kariuomenè. Netrukus, rugsèjo 11 d., Tarybų Rusijos vyriausybė pasiūlè pradèti taikos derybas. Kovoms su bolševikais pasibaigus, buvo ịvertinti visų karinių dalinių vadai, kurių sėkmingas vadovavimas priartino pergalę Dauguvos fronte. Už pasiektą pergalę pirmiausia buvo pagerbtas vyriausiasis kariuomenès vadas generolas Silvestras Žukauskas. Valstybès Prezidentas A. Smetona 1919 m. rugsejjo 13 d. paskelbè ịsakymą:

"Jo Ekscelencijai

Vyriausiam Kariuomenès Vadui

Generolui Žukauskui

Paskutiniai mūsų narsios kariuomenès mūšiai su priešininku kurie nuo rugpjūčio 26 d. š. m. ejo visu Dauguvos frontu 120-ties kilometru platumo, Tamstai, Ponai Generolai vadovaujant, pasibaigè visišku mūsu laimejjimu. ... Visa Lietuva dèkinga Tamstai, Ponai Generolai ir visiems savo sūnums-Dauguvos narsuoliams, kurie Tamstos vedami, išvadavo te vų žemę ir jos gyventojus iš rusų bolševikų jungo ............Gi už rugpjūčio Dauguvos mūšį ženklinu Tamstą Ponai Generolai, trečiojo ir antrojo laipsnio Lietuvos karžygių kryžiumi"'.

1919 m. spalio 9 d. Valstybės Prezidento isakymu Nr. 255 už parodytą narsumą kovose su bolševikais Kryžiumi "Už Tẻvynę" buvo apdova-

\footnotetext{
${ }^{17}$ Indrašius V. Nepriklausomybės kovų riteriai // Gimtinè. 1997 m. kovo 1-31 d. Nr. 3. P.1.

${ }^{18}$ Lesčius V. Lietuvos kariuomenè 1918-1920. V. 1998. P. 240

${ }^{19}$ Vyriausiojo Karo Vado isakymas Nr. 35. 1919 m.; CVA F 384. Ap. 2. B. 572 (ld.) Lietuvos 34
} 
nota vyriausioji Lietuvos kariuomenès vadovybè. 1-ojo laipsnio kryžiumi "Už Tèvynę" buvo apdovanota 10 karininkų:

1-osios brigados vadas karininkas Pranas Liatukas, 2-osios brigados vadas karininkas Stasys Nastopka, 1-ojo pėstininku pulko vadas karininkas Kazys Ladyga, 2-ojo pėstininku pulko vadas karininkas Vincas Glovackis, Vilniaus bataliono vadas karininkas Kazys Škirpa, Panevėžio bataliono vadas karininkas Jonas Variakojis, Joniškèlio bataliono vadas karininkas Aleksandras Jakaitis, Ukmergès batalono vadas karininkas Jurgis Kubilius, instruktorius pulkininkas Maksimas Katche, pulkininkas Konstantas Kleščinskas.

2-ojo laipsnio Kryžiumi "Už Tẻvynę" apdovanoti: 1-ojo pėstininku pulko vadas karininkas Kazys Ladyga, Marijampolès bataliono vadas karininkas Jurgis Butkus, Panevėžio bataliono vadas karininkas Jonas Variakojis, instruktorius pulkininkas Maksimas Katche ${ }^{20}$.

Buvo ruošiamasi apdovanoti ne tik vadus, bet ir karius bei aukštesniuosius karininkus. Kariuomenès dalyse buvo toliau renkama medžiaga apie pasižymejjusius kovose su bolševikais. $1919 \mathrm{~m}$. spalio $30 \mathrm{~d}$. Valstybės Prezidento issakymu už narsumą mūšiuose su priešu 1-ojo laipsnio Kryžiumi "Už Tẻvynę" buvo apdovanota didelè kareivių ir karininkų grupè341 asmuo. Iš jų Marijampolès bataliono 6 karininkai: Genrikas Songinas, Liudas Žukauskas, Aleksandras Šimkus, Vosylius Gelgermanas, Jonas Banevičius, Juozas Lanskoronskis. Iš Joniškèlio bataliono 2 karininkai: Valerijonas Umbrasas ir Jurgis Gorodeckis. Iš 2-ojo pėstininkų pulko 6 karininkai: Jonas Motiejūnas-Valevičius, Konstantas Butleris, Eduardas Noreika, Antanas Sinickis, Juozas Andriūnas ir Vladas Žutovtas. Iš 1osios baltgudžiu kuopos-2 karininkai: Jurgis Plisko ir Povilas Lasinskis. Iš Vilniaus bataliono-2 karininkai: Antanas Jakštas ir Pranas Kabaila. Iš viso 1-ojo laipsnio Kryžiumi "Už Tẻvynę" apdovanota 18 karininkų.

2-ojo laipsnio Kryžiumi "Už Tẻvynę" apdovanoti 2 karininkai iš Marijampolès bataliono: Alfonsas Sinkevičius ir Jonas Kairiūnas ir 2 karininkai iš 2-ojo pėstininku pulko: Jonas Laurinaitis ir Andrius Butkevičius ${ }^{21}$.

Kryžiumi "Už Tėvynę" apdovanotas karininkas Antanas Sinickis žuvo 1919 m. rugpjūčio 26 d. latvių žemèje ties Rautenzès dvaru ${ }^{22}$. Kari-

\footnotetext{
${ }^{2 \circ}$ Lietuvos kariuomenei įstatymas Nr. 175. § 10. 1919 m. spalio 25 d.; Kariškių žodis. 1919. Nr. 31. P. 241-242

${ }^{21}$ Lietuvos kariuomenei įsakymas Nr. 183. $\$ 1.1919$ m. lapkričio $16 \mathrm{~d}$

${ }^{22}$ Atspindžiai. 1922 m. gegužès mèn. P. 4; Kardas. 1934 m. Nr. 19. P. 376.
} 
ninkas Jurgis Plisko su gudu batalionu kovèsi prieš bolševikus Daugpilio fronte ir žuvo $1919 \mathrm{~m}$. rugpjūčio $28 \mathrm{~d} .{ }^{23}$ Karininkas Valerijonas Umbrasas pasižymèjo kovose su bolševikais, ypač mūšyje ties Ilukšta ${ }^{24}$. Už pasižymèjimą dar 1919 m. balandžio mènesí mūšyje ties Strošiūnais I apdovanoti du karininkai kuopu vadai-Pranas Kabaila ir Antanas Jakštas. ${ }^{25}$

Surinkus daugiau medžiagos apie pasižymejjusius kovose su bolševikais karius, buvo išleistas dar vienas ịsakymas dèl apdovanojimo.

1919 m. gruodžio 6 d. Valstybès Prezidento issakymu už pasižymëjimą mūšiuose 1-ojo laipsnio Kryžiumi "Už Tèvynę" buvo apdovanoti 173 kareiviai ir karininkai. Iš jų iš 1-ojo pėstininkų pulko-16 karininkų: Bronius Bilminas, Mikas Rèklaitis, Stasys Bagdonas, Jonas Bartoševičius, Jonas Zolotorius, Adomas Džiuvè, Petras Zablockas, Jonas Bužinskas, Ottas Durcholcas (Otto Durcholc), Mikas Repšys, Vladas Ikamas, Juozas Plentas, Petras Daukšys, Antanas Povilaitis, Jurgis Sidaravičius ir Vladas Skorupskis.

Iš 3-iojo pèstininkų pulko-karininkas Ignas Musteikis, iš Ukmergès bataliono-4 karininkai: Silvestras Leonas, Bronius Vincas Aleksandravičius, Stasys Rekašius ir Petras Jurgaitis.

Iš Vilniaus bataliono-3 karininkai: Vytautas Bagdanavičius, Mikas Micevičius ir Stasys Raštikis. Iš 1-ojo raitelių pulko-2 karininkai: Genrikas Goštautas ir Albertas Šileris, o iš 1-ojo artilerijos pulko-karininkas Justinas Kibirkštis.

Iš viso 1-ojo laipsnio Kryžiumi "Už Tẻvynę" apdovanoti 27 karininkai.

2-ojo laipsnio Kryžiumi "Už Tèvynę" apdovanoti 4 karininkai. Iš 1-ojo péstininkų pulko-Povilas Dundulis ir Stasys Marcinkevičius, iš 1ojo artilerijos pulko-Matas Pečiulionis ir Bronius Paškevičius ${ }^{26}$.

Karininkas Jurgis Sidaravičius kovėsi su bolševikais Zarasų fronte ties Salaku ir Antaliepte ir žuvo kautynèse 1919 m. rugpjūčio 24 d. netoli Balčiu dvaro bolševikams užpuolus jo būrį. Apdovanotas po mirties ${ }^{27}$.

\footnotetext{
${ }^{23}$ Kardas. 1934 m. Nr. 17. P. 333

${ }^{24}$ Atspindžiai. 1921. Nr. 2, sausio mèn. P. 5

${ }^{25}$ Butkus S. 5 - sis pėstininkų didžiojo Lietuvos Kunigaiščio Kęstučio pulkas // Karo archyvas,1925.T. 1. P. 158 - 159; Lesčius V. Lietuvos kariuomenė 1918 - 1920. V. 1998. P.263 264

${ }^{26}$ Lietuvos kariuomenei issakymas Nr. 202. § 1. 1919 m. gruodžio 9 d.

${ }^{27}$ Iš a. a. karūžo J.Sidaravičiaus biografijos // Kariškių žodis. 1919 Nr. 20. P. 157-158; Kardas. 1934 m. Nr. 22. P. 447
} 
5-ojo pėstininkų pulko 3-iosios kuopos vadas karininkas Vytautas Bagdanavičius apdovanotas už tai, kad jo kuopa ịvykdžiusi drąsu puolimą pirmoji ižengè i Ežerènus ir užèmé pavestaji pozicijos barą. Mūšiu metu V. Bagdanavičius buvo lengvai sužeistas, tačiau liko rikiuotėje ${ }^{28}$.

Karininkas Mikas Micevičius buvo apdovanotas už 1919 m. rugpjūčio 23-24 d. bolševikų atramos punkto-Mažvilių užèmimą ${ }^{2} *$.

Karininkas Stasys Raštikis, būdamas puskuopès vadu, 1919 m. rugpjūčio 26 d. sukèlè sąmyšš tarp priešo ties Svilčiko palivarku ${ }^{30}$.

Antrą kartą Kryžiumi "Už Tẻvynę" buvo apdovanoti artilerijos karininkai M. Pečiulionis ir B. Paškevičius. M. Pečiulionis-už Turmanto ir Kaukonių išvadavimą*. Karininkas Bronius Paškevičius buvo apdovanotas už tai, kad 1919 m. rugpjūčio 25 d. sunkiomis ir gyvybei pavojingomis sąlygomis taip suorganizavo baterijos šaudymą, kad priešą privertè trauktis ${ }^{32}$.

\section{KOVOSE SU BERMONTININKAIS PASIŽYMĖJUSIEJI KARININKAI.}

\section{Prasideda apdovanojimai vyties kryžiumi}

1919 m. liepos pabaigoje i Šiaurès Lietuvą isiveržè pirmieji vokiečių ir rusų baltagvardiečių, vadinamujų bermontininkų, daliniai. Spalio mėnesio pradžioje jie užèmė Šiaulius, o iki lapkričio vidurio-Biržus, Radviliški, Linkuvą, Viduklę, Raseinius, Jurbarką. 1919 m. spalio 3 d. Valstybès Prezidento issakymu Nr. 256 už narsuma, ištvermę ir pavyzdingą pareigų ejimą bermontininkų užimtoje teritorijoje 1-ojo laipsnio Kryžiumi "Už Tèvynę" buvo apdovanotas Šiaulių komendantas karininkas Adolfas Birontas $^{33}$.

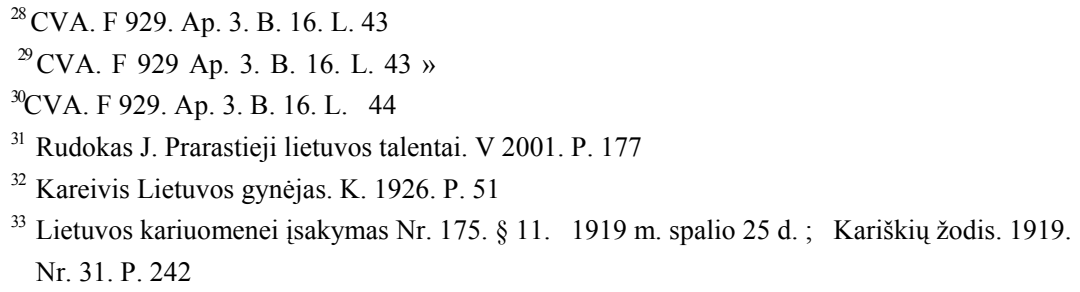


Pagrindiniai Lietuvos kariuomenès mūšiai su bermontininkais prasidejjo $1919 \mathrm{~m}$. lapkričio $21 \mathrm{~d}$.

1-asis ir 2-asis pėstininkų pulkai kovojo Radviliškio rajone. Radviliški puolè 2-ojo pėstininku pulko mjr. J. Motiejūno-Valevičiaus vadovaujamas 1 -asis batalionas. Atakos metu buvo sunkiai sužeisti leitenantai Serafinas Oželis ir Petras Urbakonis. Netrukus abu miré ${ }^{34}$.

Lapkričio $22 \mathrm{~d}$. i kautynes su bermontininkais ịsijungęs 1 -asis pèstininkų didžiojo Lietuvos kunigaikščio Gedimino pulkas po 14 valandų mūšio atkovojo Radviliški. Šiose kautynėse narsumu ir sumanumu pasižymejjo pulko vadas mjr. V. Skorupskis bei karininkai: mjr. V. Saudzis, kpt. K. Sprangauskas, kpt. S. Marcinkevičius, kpt. A. Šmidtas, vyr. 1tn. N. Zabulionis, vyr. ltn. P. Norkūnas, vyr. ltn. A. Ambraziejus, ltn. A. Treideris.

Meškuičiu apylinkėse, tarp Joniškio ir Šiaulių, kovojo 4-asis pėstininkų pulkas, vadovaujamas karininko J. Variakojo. Dešiniajame sparne kovèsi 5 kuopa. Mūšio metu buvo mirtinai sužeistas kuopos vadas karininkas Karolis Hofmanas.

Kautynėse su bermontininkais pasižymėjo 5-ojo pėstininku pulko 4-osios kuopos vadas vyr. 1tn. Pranas Grigas. Jo vadovaujama kuopa 1919 m. lapkričio 20 d. atkovojo Šiaulaičiu ir Vaitkaičių kaimus, paėmė iš priešo didelị kieki amunicijos, lapkričio $22 \mathrm{~d}$. iš bermontininku atsikovojo garveži ir vagoną. Visuose šiuose susiremimuose asmeninę drąsą rodè vyr. ltn. Pranas Grigas ${ }^{35}$. Pasibaigus kovoms su bermontininkais, prasidejjo labiausiai pasižymejjusių kareivių, puskarininkių ir karininkų apdovanojimas Kryžiumi "Už Tẻvynę".

Atskiru isakymu buvo ivertinti mjr. Vlado Skorupskio nuopelnai.

$1920 \mathrm{~m}$. sausio $20 \mathrm{~d}$. Valstybès Prezidento A. Smetonos įsakymu laikinai einantis 1-ojo pesstininku didžiojo Lietuvos kunigaikščio Gedimino pulko vado pareigas majoras Vladas Skorupskis už pasižymėjimą Radviliškio mūšyje, buvo apdovanotas 2-ojo laipsnio Kryžiumi "Už Tẻvynę"36.

$1920 \mathrm{~m}$. sausio $22 \mathrm{~d}$. Valstybès Prezidento i̇sakymu už pasižymėjimą mūšiuose su priešu 1-ojo laipsnio Kryžiumi "Už Tèvynę" buvo apdovanoti 59 kareiviai ir karininkai. Iš jų iš 1-ojo artilerijos pulko: kpt. Vytau-

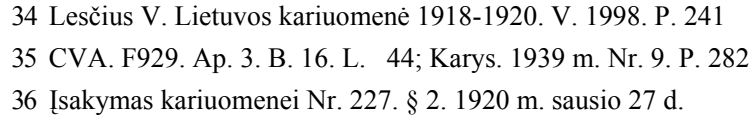


tas Landsbergis, 2-ojo pėstininkų didžiojo Lietuvos kunigaikščio Algirdo pulko ltn. Kazys Ališauskas, ltn. Petras Urbakonis, puskarininkis, einantis karininko pareigas, Serafinas Oželis (po mirties), karininkas Bronius Draugelis; 4-ojo pėstininkų pulko: vyr. ltn. Karolis Hofmanas (po mirties), vyr. ltn. Emilius Villeris, karininkas Romualdas Vaitkevičius; 5ojo pėstininkų pulko-vyr. ltn. Pranas Grigas. Iš viso 1-ojo laipsnio Kryžiumi "Už Tẻvynę" apdovanoti 9 karininkai.

2-ojo laipsnio Kryžiumi "Už Tèvynę" apdovanoti 2-ojo didžiojo Lietuvos kunigaikščio Algirdo pulko kpt. Jonas Petruitis, 1-ojo artilerijos pulko kpt. Juozas Giedraitis, 6-ojo pėstininkų Pilènų kunigaiščio Margio pulko vyr. 1tn. Juozas Barkauskas ${ }^{37}$.

1920 m. sausio 22 d. Valstybès Prezidento issakymas dèl apdovanojimų nepaliete kitų pasižymèjusių karių, todèl prireikè dar vieno įsakymo. Jame pasižymëję kovose turejjo būti apdovanoti ne Kryžiumi "Už Tẻvynę", bet Vyties kryžiumi. 1920 m. pradejjus apdovanoti Vyties kryžiumi atsirado netikslumas. Vietoje žodžių "su kalavijais", "be kalavijų" kaip numatyta ịstatyme, isakymuose buvo rašoma "Vyties Kryžius su kardais", "Vyties Kryžius be kardų". Ši tradicija buvo tokia stipri, kad net persidavè i 1927 m. ir 1930 m. ịstatymus. Iš tikruju Vyties kryžiaus ženkle vaizduojami ne kardai, o kalavijai*.

Jau $1920 \mathrm{~m}$. vasario 13 d. Valstybès Prezidento isakymu už pasižymèjimą mūšiuose su priešu 1-ojo laipsnio Vyties kryžiumi apdovanoti 42 kareiviai ir karininkai: 1-ojo pėstininkų didžiojo Lietuvos kunigaikščio Gedimino pulko kpt. Kazys Sprangauskas, vyr. 1tn. Napoleonas Zabulionis, vyr. 1tn. Vincas Kindurys, ltn. Edvardas Rulinskas, 3-iojo pėstininku pulko vyr. 1tn. Teodoras Šostakas, Artilerijos pulko 4-osios baterijos 1tn. Vincas Jasulaitis.

2-ojo laipsnio Vyties kryžiumi apdovanotas 1-ojo péstininkų didžiojo Lietuvos Kunigaikščio Gedimino pulko mjr. Vincas Śaudzis ${ }^{38}$. Visi buvo apdovanoti 1-osios rūšies Vyties kryžiumi, nors isakymo rengejai to ir nenurode.

\footnotetext{
* Straipsnio autorius, nenorèdamas keisti dokumentų dvasios, paliko i̇sakymuose vartojamus pavadinimus nepakeistus.

${ }^{37}$ Lietuvos kariuomenei i̇sakymas Nr. 230. § 1. 1920 m. sausio 29 d.; Kariškių žodis. 1920 Nr. 8. P. 63

${ }^{38}$ Lietuvos kariuomenei įsakymas Nr. 243. § 1. 1920 m. vasario 18 d.; Kariškių žodis. 1920.Nr. 11. P. 95 .
} 
Ltn. V. Jasulaitis buvo pristatytas apdovanoti 1-ojo laipsnio Vyties kryžiumi su kardais už kautynėse Jogėlaičių kaime sunaikintą bermontininku sunkiuju kulkosvaidžių kuopą ${ }^{39}$. Vyr. ltn. T. Sostakas buvo apdovanotas už pasižymėjimą kovose su bolševikais Daugpilio fronte.

1920 m. balandžio 12 d. paskelbtas Laikinai einančio vyriausiojo kariuomenès vado pareigas generolo leitenanto Galvydžio-Bykausko įsakymas Nr. 298, kuriuo remiantis $1920 \mathrm{~m}$. vasario 3 d. Prezidento įstatymu anksčiau apdovanoti Kryžiumi "Už Tẻvynę" buvo laikomi apdovanotais Vyties kryžiumi: "Kariškius "Lietuvos Kariuomenei" isakymų Nr. 155; 175 $\S 10,11 ; 183 ; 202,227$ §2 ir 230 apdovanotus Kryžiumi "Už Tẻvynę" laikyti nudovanotais "Vyties Kryžiumi". Pamatas: "Lietuvos Kariuomenei" Isakymas Nr. $234 \S 1 " 40$.

Po kovų su bolševikais, bermontininkais ir vidaus priešais buvo paskelbta naujų i̇sakymų dèl apdovanojimų.

$1920 \mathrm{~m}$. balandžio 7 d. Valstybès Prezidento A. Smetonos isakymu už pasižymèjimą mūšiuose su priešu 1-ojo laipsnio Vyties kryžiumi apdovanota 10 kareivių ir karininkų.

Vyties kryžiumi su kardais apdovanoti autobataliono vyr ltn. Sergejus Fanstilis (už pasižymèjimą malšinant sukilimą Kaune; apie S. Fanstili žr. toliau), 2-ojo pesstininkų didžiojo Lietuvos kunigaikščio Algirdo pulko kpt. Stasys Dabulevičius, Mažeikiu miesto ir apskrities karo komendantas vyr. 1 tn. Jonas Šlepetys. ${ }^{41}$

1920 m. gegužès 12 d. Prezidento issakymu už pasižymėjimą mūšiuose 1-ojo laipsnio Vyties kryžiumi su kardais apdovanotas 9-ojo pėstininkų Lietuvos kunigaikščio Vytenio pulko ltn. Pranas Pučekas ${ }^{42}$.

\section{PARODŽIUSIEJI NARSUMĄ KOVOJE SU VIDAUS PRIEŠAIS-MALŠINANT PANEMUNĖS SUKILIMA}

Vienas iš kritišku atsikuriančios Lietuvos valstybès gyvenimo momentu buvo Panemunès kareivių sukilimas Kaune 1920 m. vasario 21-23 d. Pane-

\footnotetext{
${ }^{39}$ CVA F 930. Ap. 5. B. 1045. L. 1; Jasulaitis V. Lietuvos kariuomenès artilerijos pulkininkas

Vincas Jasulaitis. V. 1998. P. 7, 30, 35

${ }^{40}$ Lietuvos kariuomenei issakymas Nr. 298. § 12. 1920 m. balandžio $12 \mathrm{~d}$.

${ }^{41}$ Lietuvos kariuomenei įsakymas Nr. 300. § 2. 1920 m. balandžio 14 d.

${ }^{42}$ Lietuvos kariuomenei ịsakymas Nr. 335. § 2. 1920 m. gegužès 21 d. 113
} 
munès sukilimo organizatorių tikslas buvo pasinaudojus sunkia ekonomine ir politine Lietuvos padètimi nuversti vyriausybę ir sugriauti atsikuriančios nepriklausomos Lietuvos valstybę.

Pagrindinę kovos prieš sukilimą atramą sudarė 8-ojo pėstininkų Kauno kunigaikščio Vaidoto pulko ir 6-ojo pesstininkų Pilènų kunigaikščio Margio pulko kareiviai ir karininkai, parodę ištikimybę Lietuvos valstybei.

1920 m. gegužès 12 d. Valstybės Prezidento A. Smetonos įsakymu už pasižymèjimą malšinant sukilèlius Kaune $1920 \mathrm{~m}$. vasario 21-23 d. Vyties kryžiumi su kardais apdovanoti 26 kareiviai ir karininkai. 1-ojo laipsnio Vyties kryžiumi apdovanotas 8-ojo pėstininku Kauno kunigaikščio Vaidoto pulko ltn. Pranas Maželis.

2-ojo laipsnio Vyties kryžiumi apdovanoti 8-ojo pėstininku Kauno kunigaikščio Vaidoto pulko kpt. Petras Jurgaitis ir 6-ojo pėstininkų Pilènų kunigaikščio Margio pulko ltn. Vosylius Gelgermanas ${ }^{43}$.

Praejjus keliems mènesiams, $1920 \mathrm{~m}$. rugsėjo 1 d., einančio Respublikos Prezidento pareigas A. Stulginskio įsakymu už pasižymėjimą 1920 m. vasario 21-23 d. malšinant Kaune sukilëlius 1-ojo laipsnio Vyties kryžiumi su kardais apdovanotas 6-ojo pestininkų Pilènų kunigaikščio Margio pulko vyr. ltn. Jurgis Kenigšteteris ${ }^{4}$. 1919 m. gruodžio 1 d. buvo isteigtas autobatalionas. Sukilimo metu dalis bataliono kareivių dalyvavo vykusiuose neramumuose. Bataliono vadui $\mathrm{S}$. Fanstiliui su ištikimais kareiviais pavyko išvaikyti sukilèlius, o dalị jų suimti. Už pasižymèjimą malšinant sukilimą S. Fanstilis buvo apdovanotas 1-ojo laipsnio Vyties kryžiumi su kardais ${ }^{45}$. (Žr. 1920 m. balandžio 7 d. Valstybès Prezidento A. Smetonos isakymą).

\section{KOVOSE SU LENKAIS PASIŽYMĖJUSIEJI KARININKAI}

Nuo 1919 m. balandžio iki 1920 m. rudens lenkų kariuomenè brovėsi vis gilyn ị Lietuvos teritoriją. $1920 \mathrm{~m}$. balandžio mėnesi lenkai visas jègas nukreipè i frontą prieš bolševikus, todèl Lietuvos sargybų puldinè-

\footnotetext{
${ }^{43}$ Lietuvos kariuomenei issakymas Nr. 335. § 1. P. 1. 1920 m. gegužès $21 \mathrm{~d}$.

${ }^{44}$ Lietuvos kariuomenei issakymas Nr. 423. § 6. 1920 m. rugsėjo $3 \mathrm{~d}$.

${ }^{45}$ Lietuvos kariuomenei įsakymas Nr. 300. § 2. 1920 m. balandžio 14 d.; Vyr. ltn. Petrauskas. Auto batalionas // Mūsų žinynas. T 15. P. 304
} 
jimai susilpnëjo. Tačiau bolševikai perejjo i puolimą ir lenkai buvo priversti trauktis. Kai rusų-lenku karo veiksmai priartejo prie Lietuvos ribų, Lietuvos vyriausybé paskelbé neutraliteta. $1920 \mathrm{~m}$. liepos $12 \mathrm{~d}$. buvo pasirašyta Lietuvos taikos sutartis su Sovietų Rusija. Vilnių užėmę bolševikai, vykdydami sutarti, ji perdave Lietuvai. 1920 m. rugpjūčio 16-19 d. prie Vyslos bolševikai buvo sumušti ir priversti bègti. Rugpjūčio $28 \mathrm{~d}$. lenkų kariuomenè užèmė Lietuvos kariuomenès kontroliuotą Augustavą, o rugpjūčio 30-31 d.-Suvalkus ir Seinus. 1920 m. rugsèjo 2 d. Lietuvos kariuomenès vadovybè sutelkusi daugiau jègų pradèjo puolimą. Operacijai vadovavo 2 -osios pėstininkų divizijos vadas pik. V. GrigaliūnasGlovackis. Puolè 2-asis, 5-asis, 8-asis ir 10-asis pėstininku pulkai. Buvo atkovoti Seinai, Lipskas, pasiektas Augustavas ir Suvalkų miestas. Lenkams perëjus ị kontrpuolima, mūsų kariuomenè atsitraukè. Lenkai Augustavo miškuose sutelke dideles jëgas naujam puolimui. Rugsejjo $22 \mathrm{~d}$. prasidejjusio puolimo metu labiausiai nukentèjo mūsų kariuomenès 2-asis ir iš dalies 8-asis pèstininkų pulkai. Rugsèjo 29 d. Suvalkuose prasidejjus lietuviu ir lenkų deryboms karo veiksmai buvo sustabdyti. Tačiau lenkai, pasirašę Suvalkų sutarti, ją netrukus sulaužè-užgrobè Vilnių. Sunkiuose mūšiuose su lenkai didvyriškumo pavyzdžius parodè mūsu kariai ir karininkai ${ }^{46}$. Legendiniu tapo kpt. Vinco Vitkausko vadovaujamo bataliono žygis iš apsupties Gardino fronte $1920 \mathrm{~m}$. rugséjo 23-30 d. Per 7 dienas batalionas, nuėjęs $310 \mathrm{~km}$ per priešo užimtą teritorija, pasiekẻ savuosius ${ }^{47}$.

1920 m. rugsèjo 1 d. einančio Respublikos Prezidento pareigas A. Stulginskio isakymu už pasižymèjimą mūšiuose su priešu Vyties kryžiumi su kardais apdovanota 11 kareiviu ir 1 karininkas. 1-ojo laipsnio Vyties kryžiumi apdovanotas 3-iojo pėstininkų Vytauto didžiojo pulko vyr. ltn. Antanas Ugianskis ${ }^{48}$. Apdovanojimo jis nusipelnè už pasižymèjimą ir sumanumą mūšyje su lenkais prie Vaitkuškio ir kitose kautynèse ${ }^{4}$.

1920 m. spalio 2 d. einančio Respublikos Prezidento pareigas A. Stulginskio i̇sakymu už pasižymèjimą mūšiuose su priešu 1-ojo laipsnio

\footnotetext{
${ }^{46}$ Lietuvių enciklopedija. T. XV (2 - ašis leidimas) V. 1991. P. 99 ?

${ }^{47}$ Lesčius V. Lietuvos kariuomenè 1918-1920. V. 1998. P. 283-285

${ }^{48}$ Lietuvos kariuomenei isakymas Nr. 423. § 3. 1920 m. rugsèjo 3 d.

${ }^{49}$ Majoras Ružancovas. A. a. vyr. 1tn. Antanas Ugianskis // Karys. 1922 birželio 17 d. Nr. 24. P. 182
} 
Vyties kryžiumi su kardais apdovanota 15 kareivių ir karininkų. Tarp ju trys aviacijos dalies leitenantai: Jurgis Dobkevičius, Juozas Pranckevičius ir Juozas Kumpis bei ltn. Eduardas Berentas iš Vilniaus miesto ir apskrities komendantūros ${ }^{50}$.

1920 m. spalio 9 d. lenkams sulaužius Suvalkų sutartị ir užėmus Vilnių, mūsų kariuomenė buvo priversta trauktis. Tačiau Širvintų-Giedraičiu linijoje lenkai buvo sustabdyti, o vèliau ir sumušti. Šį ruožą atkakliai gynė 7asis pėstininkų žemaičių kunigaikščio Butegeidžio pulkas, kuris buvo puolamas daug gausesnių želigovskininkų jègų. 7-ojo pèstininkų žemaičių kunigaikščio Butegeidžio pulko karių ir karininkų nuopelnai buvo įvertinti. 1920 m. lapkričio 19 d. einančio Respublikos Prezidento pareigas A. Stulginskio isakymu už pasižymėjimą mūšiuose su priešu pirmosios rūšies 1-ojo laipsnio Vyties kryžiumi apdovanoti 24 kareiviai ir karininkai. Tarp apdovanotuju buvo ir 8 karininkai iš 7-ojo pėstininkų žemaičių kunigaikščio Butegeidžio pulko: kapitonai Vincas Vitkauskas ir Petras Tarasenko, vyr. leitenantai Teodoras Balnas ir Dimitrijus Katasonovas, leitenantai Juozas Černius, Jeronimas Matelis, Antanas Štatas ir Sergejus Chamanskis. Už pasižymėjimą mūšiuose su priešu pirmosios rūšies 1-ojo laipsnio Vyties kryžiumi apdovanotas 1-ojo artilerijos pulko vyr. 1tn. Gustavas Albertas Šnudlas ${ }^{51}$.

Vyr. ltn. T. Balnas buvo apdovanotas už garsiąsias Širvintu kautynes. 1920 m. lapkričio 19 d. T. Balnas sugalvojo plana, kaip atkovoti Širvintas, ir buvo šio plano vykdytojas. Vaduojant Širvintas dalyvavo ir kiti Prezidento lapkričio 19 d. issakymu Vyties kryžiais apdovanoti karininkai 1tn. Jeronimas Matelis ir 1tn. Antanas Štatas ${ }^{52}$.

1920 m. lapkričio 13 d. einančio Respublikos Prezidento pareigas A. Stulginskio isakymu už pasižymèjimą mūšiuose su priešu Vilniaus miesto ir apskrities komendantūros ltn. Vladas Putvinskas (turi būti Stasys Putvinskis) apdovanotas 1-ojo laipsnio Vyties kryžiumi su kardais ${ }^{53}$.

1920 m. gruodžio 2 d. einančio Respublikos Prezidento pareigas A. Stulginskio įsakymu už pasižymèjimą mūšiuose su priešu 1-osios rūšies Vyties kryžiumi apdovanotas 21 kareivis ir karininkas.

\footnotetext{
${ }^{50}$ Isakymas kariuomenei Nr. 454. $§ 7.1920 \mathrm{~m}$. spalio $15 \mathrm{~d}$.

${ }^{51}$ İsakymas kariuomenei Nr. 492. § 1. 1920 m. lapkričio $27 \mathrm{~d}$.

${ }^{52}$ Rukša A. Kovos dèl Lietuvos nepriklausomybès. Cleveland. T.III. 1982. P. 354

53 Isakymas kariuomenei Nr. 484. § 1. 1920 m. lapkričio 16 d.
} 
2-ojo laipsnio Vyties kryžiumi apdovanoti 9-ojo pėstininkų Lietuvos kunigaikščio Vytenio pulko 1-osios kuopos vadas vyr. ltn. Pranas Pučekas ir Artilerijos pulko 6-osios baterijos vadas vyr. 1tn. Gustavas Šmidtas. 1-ojo laipsnio Vyties kryžiumi apdovanota 13 karininkų: 3-iojo pėstininkų didžiojo Lietuvos kunigaikščio Vytauto pulko vadas mjr. Jonas Gricius, 3-iosios divizijos štabo viršininkas kpt. Balys Jakutis, keturi 6-ojo pèstininkų Pilènų kunigaikščio Margio pulko karininkai: pulko vado padejejjas majoras Antanas Stapulionis, 2-ojo bataliono vadas kapitonas Pilypas Ignatavičius, 1-osios kuopos vadas ltn. Alfonsas Basiulis (turi būti Baniulis) ir 4-osios kuopos jaun. karin. 1tn. Vytautas Buragas, taip pat keturi 9-ojo pėstininku Lietuvos kunigaikščio Vytenio pulko karininkai: 1-ojo bataliono vadas kpt. Vladas Girštautas, 2-ojo bataliono vadas kpt. Stasys Šileika, 1-osios kuopos jaun. kar. 1tn. Leonas Jonaitis ir 1-osios kulkosvaidžių kuopos jaun. kar. ltn. Antanas Breimelis.

1-ojo laipsnio Vyties kryžiumi apdovanoti ir trys artilerijos pulko 6-osios baterijos karininkai kpt. Teodoras Vitte, vyr. ltn. Kostas Avižienis ir ltn. Povilas Meškauskas ${ }^{54}$.

Isakyme paminètas vyr. 1 tn. Pranas Pučekas buvo apdovanotas už pasižymëjimą lenkų fronte $1920 \mathrm{~m}$. spalio $9 \mathrm{~d}$., kai su 30 kareivių ir 2 kulkosvaidžiais atrèmé gausaus priešo su 2 šarvuotais automobiliais puolimai ${ }^{55}$.

$1920 \mathrm{~m}$. gruodžio $31 \mathrm{~d}$. einantis Respublikos Prezidento pareigas A. Stulginskis už pasižymèjimą mūšiuose su priešu pasirašè du ísakymus dèl apdovanojimo. Pirmuoju issakymu pirmosios rūšies Vyties kryžiumi apdovanoti 57 kareiviai ir karininkai. 1-ojo laipsnio Vyties kryžiumi apdovanota 13 karininkų: laikinai einantis 1-osios pès- tininku divizijos vado pareigas plk. ltn. Edvardas Adamkavičius,

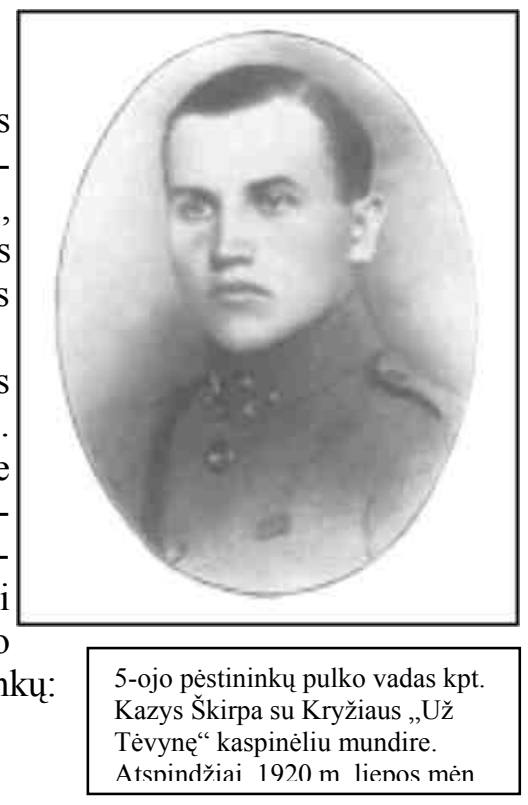

\footnotetext{
${ }^{54}$ İsakymas kariuomenei Nr. 18. §5. 1921 m. sausio 24 d. ; Karys. 1921. Nr. 9. P. 104

${ }^{55}$ Atspindžiai. $1921 \mathrm{~m}$. Nr. 5, gegužès mèn. P. 3
} 
tos pačios divizijos štabo adjutantas vyr. ltn. Stasys Pundzevičius, 5-ojo pėstininkų didžiojo Lietuvos kunigaikščio Kęstučio pulko 2-osios kuopos vadas kpt. Karolis Remežas (turi būti Remeza), 9-ojo pėstininkų Lietuvos kunigaikščio Vytenio pulko adjutantas ltn. Petras Gužas, to paties pulko 1-osios kulkosvaidžiu kuopos vadas ltn. Stasys Trimakas, 4-osios kuopos vadas ltn. Vaclovas Micevičius, 4-osios kuopos jaunesnieji karininkai leitenantai Antanas Motozas (turi būti Motuzas) ir Česlovas Jonuškevičius (turi būti Januškevičius), 10-ojo pèstininkų Marijampolès pulko 2-osios kuopos vadas vyr. ltn. Mečius Krikščiūnas, to paties pulko mokomosios kuopos vadas vyr. ltn. Viktoras Kazlauskas, 1-ojo raiteliu pulko ltn. Aleksas Šilas, 2-ojo raiteliu pulko ltn. Leonas Račiūnas, 1-osios artilerijos brigados 6-osios baterijos jaun. karininkas ltn. Pranas Povilaitis $^{56}$.

Antruoju isakymu už pasižymejjimą mūšiuose 1-osios rūšies Vyties kryžiumi apdovanota 119 kareivių, karininkų, sanitarų ir vienas kunigas. Iš jų 24 karininkai. 2-ojo laipsnio Vyties kryžiumi apdovanoti: 1-osios pėstininku divizijos štabo viršininkas vyr. ltn. Juozas Lanskoronskis, 4-ojo pėstininku Lietuvos karaliaus Mindaugo pulko laikinai einantis 1-osios kuopos vado pareigas karininkas Nikolajus Kukinas ir 6-ojo pèstininkų Pilènų kunigaikščio Margio pulko 1-ojo bataliono vadas kpt. Kazys Mackevičius.

1-ojo laipsnio Vyties kryžiumi apdovanoti 4 karininkai iš 4-ojo pėstininku Lietuvos karaliaus Mindaugo pulko: 2-osios kuopos vadas vyr. 1 tn. Genrikas Šalkauskas, 7-osios kuopos vadas karininkas Pranas Puzeris- Miuleris (Puzer-Mūller),

7-osios kuopos jaunesnysis karininkas ltn. Ipolitas Žulys ir 4-osios kuopos jaunesnysis karininkas ltn. Jurgis Gegžna

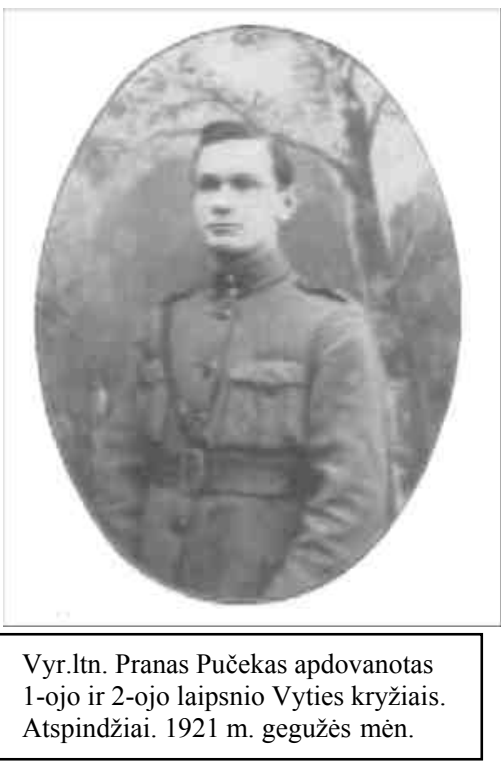

${ }^{56}$ İsakymas kariuomenei Nr. 9. § 9. 1921 m. sausio $14 \mathrm{~d}$. 
bei pulko kapelionas kunigas Vilius Balandis. 1-ojo laipsnio Vyties kryžiumi apdovanotas 6-ojo pėstininkų Pilènu kunigaikščio Margio pulko 2-osios kulkosvaidžiu kuopos vadas ltn. Jonas Kuklierius (po mirties) ir 11 karininkų iš 7-ojo pėstininkų žemaičiu kunigaikščio Butegeidžio pulko: 2-ojo bataliono vadas mjr. Andrius Kerbelis, laikinai einantis 1-osios kuopos vado pareigas 1tn. Kazys Ramanauskas, jaunesnysis karininkas ltn. Teodoras Bitvinskas, laikinai einantis 2-osios kuopos vado pareigas ltn. Juozas Andrikis, jaunesnysis karininkas ltn. Kazys Žilinskas, 4-os kuopos vadas vyr. 1tn. Vaclovas Statkevičius, jaunesnysis karininkas ltn. Bronius Šarauskas, 5-osios kuopos vadas vyr. 1tn. Antanas Kemežis, 5osios kuopos jaunesnysis karininkas 1tn. Kristupas Gudaitis, 6-osios kuopos vadas vyr. ltn. Zigmas Šalkauskas ir 6-osios kuopos jaunesnysis karininkas ltn. Leonas Kalinauskas.

1-ojo laipsnio Vyties kryžiumi apdovanoti 8-ojo pėstininkų Kauno kunigaikščio Vaidoto pulko jaunesnieji karininkai leitenantai Tadas Šakmanas ir Jonas Žmuidzinavičius, 9-ojo pėstininkų Lietuvos kunigaikščio

Vytenio pulko vadas mjr. Antanas Pa-

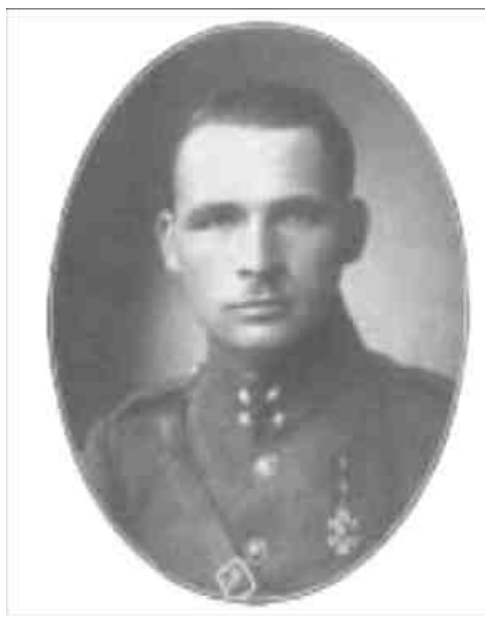
škevičius, 1-osios artilerijos brigados 10osios baterijos vyresnysis karininkas ltn. Jonas Šimkus ir Sanitarijos skyriaus viršninkas gydytojas generolas ltn. Vladas Nagevičius ${ }^{57}$. Apdovanojimo isakyme rašoma, kad Sanitarijos skyriaus viršninkas gydytojas gen. ltn. Vladas Nagevičius pasižymejo $1919 \mathrm{~m}$. rugpjūčio mènesį mūšiuose ties Kalkūnais. Jis buvo lauko sanitarijos inspektorius. Smarkiai priešo apšaudomoje teritorijoje pasiaukojamai ir narsiai tvarkè perrišamuosius punktus, prižiūrèjo sužeistuju evakavimą, rūpinosi nusilpusiu kariu maistu ir poilsiu.

Vyr. 1tn. Juozas Barkauskas su 2-ojo laipsnio Vyties kryžiumi. Atspindžiai. 1921 m. lapkričio mèn.

Apdovanoti 1-osios rūšies 1-ojo laipsnio Vyties kryžiumi gen. ltn. VNagevičių pristatė Vyriausiasis kariuomenès vadas gen. S.Žukauskas ${ }^{58}$.

${ }^{57}$ Isakymas kariuomenei Nr. 9. § 7. 1921 m. sausio 14 d.; Karys. 1921. Nr. 9. P. 102-103

${ }^{58}$ Isakymas kariuomenei Nr. 9. § 3. $1921 \mathrm{~m}$. sausio $14 \mathrm{~d}$ 
Vienas iš apdovanotojų ltn. Tadas Šakmanas pasižymėjo 1920 m. lapkričio 21 d. Širvintų-Giedraičių operacijoje ${ }^{59}$.

1920 m. rudeni, palikdamas 5-aji pèstininkų didžiojo Lietuvos kunigaikščio Kęstučio pulką, buvęs jo vadas mjr. K. Škirpa krimtosi, kad nespejo pristatyti apdovanoti "kovos atsižymejjimo ženklais" karininkų ir kareivių, kurie pasižymejjo kovose su lenkais 1920 m. rugsëjo mènesį. Apdovanojimo klausimu mjr. K. Škirpa $1921 \mathrm{~m}$. sausio 27 d. raštu kreipèsi i armijos vadą, apgailestavo, kad nespejo surinkti reikalingos medžiagos iš kuopų ir komandu vadų, taip pat iš 7-osios baterijos vado ir šarvuotu automobilių komendanto, kurie buvo jo žinioje. Skundèsi, kad 5-ojo pulko vadu paskirtas pik. ltn. M. Velykis, i kurị kreipessi mjr. K. Škirpa, nesurinko reikalaujamos medžiagos. Neapdovanoti karininkai ir kareiviai jaučiasi nuskriausti, todèl mjr. K. Škirpa prašè armijos vadą isakyti, kad pik. ltn. M. Velykis atsiųstų medžiagą dèl apdovanojimų ${ }^{60}$.

Pasižymejjusieji 5-ojo pėstininkų pulko karininkai buvo pagerbti vèliau-1923 m.

\section{KARININKAI, APDOVANOTI UŽ NARSUMĄ KOVOSE SU LENKAIS NEUTRALIOJOJE ZONOJE}

Lietuvos ir Lenkijos vyriausybès bei karo vadovybès, vykdydamos Tautu Sajungos komisijos reikalavimą, nuo $1920 \mathrm{~m}$. griežtai draudè savo kariams peržengti neutraliają zoną. Tačiau $1921 \mathrm{~m}$. pabaigoje lenkai nedidelèmis partizanu grupèmis pradèjo užpuldinèti Lietuvos sargybas ịvairiose Širvintu-Giedraičiu rajono vietose. Pastebèta, kad tuose užpuolimuose dalyvaudavo reguliariosios kariuomenès kareiviai, kartais su uniformomis. Prie neutraliosios zonos stovejusio 4-ojo pėstininku pulko vadas pik. Pranas Tamašauskas savarankiškai ir savo atsakomybe iš kariu organizavo partizanų būrị ir perrengęs nusiunte ji $i$ neutraliają zoną. Tam 25 žmonių būriui vadovauti pasisiūle ltn. Petras Inickas, o pavaduotoju paskirtas 1tn. Domas Kavaliauskas. Taigi nuo 1922 m. gegužès 1 d. iki 1923 m. birželio vidurio 4-ojo pesstininkų Lietuvos karaliaus Mindaugo pulko kariai partizanai veikè neutraliojoje zonoje.

${ }^{59}$ CVA F 930. Ap. 5. B. 2615. L. 1 - 8 »

${ }^{60}$ CVA. F 929 Ap. 9. B.16. L. 52 
4-ojo pėstininkų Lietuvos karaliaus Mindaugo pulko 33 labiausiai pasižymèję kariai partizanai buvo apdovanoti Vyties kryžiais, iš jų aštuoni leitenantai:

Kazys Taruška. Pradejjo vadovauti partizanams po ltn. P. Inicko. Ypač pasižymėjo $1923 \mathrm{~m}$. naktį iš sausio 4 d. i 5 d. puolant lenkų ulonus ir jų partizanų štabą Avižonių kaime, bei sumušant lenkus naktị iš sausio 11 d. i sausio $12 \mathrm{~d}$. Širvintose.

Kostas Dulksnys. Pasižymėjo drąsa ir narsumu visose kautynėse su lenkais vadovaudamas partizanu grupèms nuo $1923 \mathrm{~m}$. sausio $1 \mathrm{~d}$. iki partizanų veiklos pabaigos.

Kazys Petkevičius. Pasižymėjo visose kautynèse su lenkais nuo 1923 m. sausio 1 d. iki partizanų veiklos Širvintose pabaigos. Paskutiniame mūšyje būdamas sunkiai sužeistas nepaliko rikiuotès, kol lenkai buvo išvyti iš Širvintų.

Jurgis Tumavičius. Nuo 1922 m. lapkričio 15 d. iki 1923 m. kovo 1 d. dalyvavo visose kautynėse su lenkais, vadovavo partizanų grupėms.

Stasys Eidukaitis. Savo drąsia iniciatyva su keliolika drąsuolių pasižymėjo puldamas ir išvaikydamas lenkų partizanus iš Kraujaleidžių kaimo 1923 m. naktị iš sausio $10 \mathrm{~d}$. į $11 \mathrm{~d}$.

Alfonsas Antanaitis. Vadovavo partizanų būriui Giedraičiuose, gynè miesteli nuo lenkų nuo $1923 \mathrm{~m}$. sausio $1 \mathrm{~d}$. iki birželio $13 \mathrm{~d}$.

Benediktas Svylas. Pasižymejjo 1923 m. naktị iš sausio 4 d. i 5 d. puolant lenkų ulonus ir lenkų partizanų štabą Avižonių kaime, kai su keliais drąsuoliais atėmè iš jų vieną sunkuji kulkosvaidị.

Domas Kavaliauskas-pirmasis partizanų būrio vado pavaduotojas.

Būrio vadas Petras Inickas apdovanotas nebuvo, nes jau turejo 1ojo ir 2-ojo laipsnio Vyties kryžius ${ }^{61}$.

1923 m. vasario 3 d. Tautų Sajungos Taryba rekomendavo Lietuvai ir Lenkijai pasidalyti neutraliają zoną. Lenkija šią rekomendaciją prièmė, nes norejo, kad jos užgrobtos Lietuvos sritys būtu jai pripažintos. Lietuvos vyriausybė pareiške Tautu Sajungai protestą. Lenkai ėmè ruoštis neutraliają zoną užimti vienašališkai. Lenkiją ypač domino RūdiškiųValkininkų-Varėnos ruožas, kad galètų naudotis geležinkeliu GardinasVilnius. Ši barą saugojo 6 pesstininkų Pilènų kunigaiščio Margio pulkas. Pulkui vadovavo pik. ltn. Pranas Tvaronas.

${ }^{61}$ CVA. F 929 Ap. 3. B. 774. L. 3, 17-18. Buvusio 4 pesstininkų pulko vado gen. P.Tamašausko atsiminimai.

121 
1923 m. vasario 12-14 d. lenku policijos dalys Valkininkų-Rūdiškių bare užèmė keletą kaimų neutraliojoje zonoje, vasario $15 \mathrm{~d}$. pradejjo pulti lietuvių sargybas. Pulko vadas pik. ltn. P. Tvaronas permetė iš rezervo 2 batalionus atsiimti užimtu vietovių. 3-ioji kuopa, vadovaujama kpt. Soltano Panteleono, atkovojo Strielčiškius ir Zakarus, 2-oji kuopa - Kaniūkų kaimą. Trys bataliono kuopos vasario $17 \mathrm{~d}$. susigrą̌ino Gudakiemio kaimą. Lenkai vis dèlto laimèjo svarbu Valkininkų-Rūdiškių geležinkelio ruožą. Kautynèse žuvo 8 kareiviai ir 1 karininkas iš 6-ojo pėstininku pulko, o 9 kareiviai pateko į nelaisvę. Už parodyta ryžtą ir drąsą 6 karininkai ir 34 kariai buvo apdovanoti Vyties kryžiais $^{62}$.

Respublikos Prezidentas 1923 m. kovo 30 d. isakymu Nr. 43 (§ 1) pasižymejjusius kovose su lenkais 55 kareivius ir karininkus apdovanojo 1osios rūšies Vyties kryžiais.

2-ojo laipsnio - tris kariškius. Iš jų 2 karininkus:

Nr. 78-4-ojo pesstininku Lietuvos karaliaus Mindaugo pulko ltn. Kazi Tarušką. Pasižymėjo 1923 m. sausio mèn. 5-10 d.

Nr. 80-6-ojo pėstininkų Pilėnų kunigaikščio Margio pulko ltn. Joną Andriunaiti. Pasižymèjo $1923 \mathrm{~m}$. vasario 14-20 d.

1-ojo laipsnio Vyties kryžiais apdovanoti 53 kareiviai, puskarininkiai ir karininkai (iš 4-ojo pėstininku Lietuvos karaliaus Mindaugo, 6-ojo pesstininkų Pilènų kunigaikščio Margio, 1-ojo husarų ir 3-iojo artilerijos pulku) Iš jų 9 karininkai:

Nr. 1164-4-ojo péstininkų Lietuvos karaliaus Mindaugo pulko 1tn. Domą Kavaliauską. Pasižymėjo 1922 m. birželio mèn. 12-13 d.

Nr. 1168-4-ojo péstininkų Lietuvos karaliaus Mindaugo pulko ltn. Benediktą Svylą. Pasižymejjo 1923 m. sausio mèn. 5-10 d.

Nr. 1169-4-ojo pėstininkų Lietuvos karaliaus Mindaugo pulko ltn. Stasį Eidukaiti. Pasižymėjo 1923 m. sausio 5-10 d.

Nr. 1170-4-ojo pėstininkų Lietuvos karaliaus Mindaugo pulko ltn. Jurgi Tumavičių. Pasižymėjo 1923 m. sausio 5-10 d.

Nr. 1171-6-ojo pėstininkų Pilènų kunigaikščio Margio pulko vadą pik. 1tn. Praną Tvaroną. Pasižymejjo $1923 \mathrm{~m}$. vasario 14-20 d.

Nr. 1172-6-ojo pesstininkų Pilènų kunigaikščio Margio pulko kpt. Soltaną Panteleoną. Pasižymėjo 1923 m. vasario 14-20 d.

${ }^{62}$ Rukša A. Kovos dèl Lietuvos nepriklausomybès. Cleveland. 1982. P. 405-411 
Nr. 1173-6-ojo pėstininkų Pilėnų kunigaikščio Margio pulko kpt. Joną Ignatavičių. Pasižymėjo $1923 \mathrm{~m}$. vasario 14-20 d.

Nr. 1174-6-ojo pėstininkų Pilènų kunigaikščio Margio pulko ltn. Tomą Kuktą. Pasižymejjo 1923 m. vasario 14-20 d.

Nr. 1175-6-ojo pėstininkų Pilènų kunigaikščio Margio pulko ltn. Liudą Tugaudị. Pasižymèjo $1923 \mathrm{~m}$. vasario 14-20 d.

Iš viso 1-ojo laipsnio Vyties kryžiais apdovanoti 53 kareiviai, puskarininkiai ir karininkai (iš 4-ojo pèstininkų Lietuvos karaliaus Mindaugo, 6-ojo pėstininkų Pilènu kunigaikščio Margio, 1-ojo husaru ir 3-iojo artilerijos pulkų) ${ }^{63}$.

\section{PIRMOSIOS VYTIES KRYŽIAUS ORDINO TARYBOS İTEIGIMAS 1923 M. PASKUTINIEJI APDOVANOJIMAI PIRMOSIOS RŪŠIES VYTIES KRYŽIUMI}

Krašto apsaugos ministras Balys Sližys peržiūrèti dar likusiems pristatymams apdovanoti Vyties kryžiumi, $1923 \mathrm{~m}$. gegužès 5 d. isakymu sudare Vyties kryžiaus ordino tarybą. Tarybos pirmininku buvo paskirtas 1osios rūšies ypatingu reikalu karininkas prie kariuomenès vado gen. ltn. Jurgis Kubilius, pirmininko pavaduotoju-kariuomenès inspektorius gen. 1tn. Stasys Nastopka, nariais: 1-ojo pèstininkų didžiojo Lietuvos kunigaikščio Gedimino pulko vadas pik. ltn. Vladas Skorupskas ir 12-ojo pėstininkų Kauno pulko vadas pik. ltn. Vincas Šaudzis, narių pavaduotojais 1-osios pėstininkų divizijos štabo viršininkas pik. ltn. Jonas Laurinaitis ir Karo mokslo skyriaus majoras Matas Pečiulionis ${ }^{6}{ }^{6}$. Vyties kryžiaus ordino taryba peržiūrèjo visus pristatymus, ìvertino pasižymėjusių nuopelnus ir parengè sąrašą patvirtinti Respublikos Prezidentui A. Stulginskiui.

1923 m. liepos 14 d. Respublikos Prezidento A. Stulginskio isakymu Nr. 75 apdovanojo Vyties kryžiumi su kardais pasižymèjusius kovose su Lietuvos nepriklausomybès priešais (bolševikus, lenkus ir išvaduojant Klaipèdos kraštą) 172 kareivius, puskarininkius ir karininkus, kurie dar nebuvo apdovanoti arba pasižymėjo $1923 \mathrm{~m}$. Pirmosios rūšies 2-ojo laips-

\footnotetext{
${ }^{63}$ [sakymas kariuomenei Nr. $62 \S 1,1923$ m. balandžio 23 d. ; Karys. 1923. Nr. 18. P. 223

${ }^{64}$ Isakymas kariuomenei Nr. 85. § 1. 1923 m. gegužès 5 d.
} 
nio Vyties kryžiumi buvo apdovanota 11 karininkų, puskarininkiu ir eiliniu. 1-ojo laipsnio Vyties kryžiumi buvo apdovanotas 161 karininkas, puskarininkis ir eilinis. Iš jų buvo apdovanota: 2-ojo laipsnio Vyties kryžiumi su kardais -5 karininkai, o 1-ojo laipsnio Vyties kryžiumi su kardais-32 karininkai. Isakyme kariuomenei Nr. 136, kuriame buvo paskelbtas apdovanotuju sąrašas, Vyties kryžiaus ordino taryba pažymëjo, kad yra peržiūrejjusi pristatymus ir kaip tik tarpininkavo dèl tų, kurie šio įsakymo $\S 2$ apdovanoti. "Kiti savo laiku neišspręsti pristatymai Vyties Kryžiaus Ordeno Tarybos išspręsti neigiamai ir visas tuo klausimu susirašinėjimas šiuo baigiamas". Tai buvo paskutinis apdovanojimas pirmosios rūšies Vyties kryžiumi. vanoti:

Už kovas su bolševikais 1-ojo laipsnio Vyties kryžiumi buvo apdo-

1. Nr. 1350-1-ojo husaru pulko vadas mjr. Povilas Plechavičius. Pasižymëjo 1919 m. sausio ir gruodžio mèn.;

2. Nr. 1349-2-ojo artilerijos pulko vadas mjr. Pranas Uogintas. Pasižymejjo 1919.06.06;

3. Nr. 1347-1-ojo artilerijos pulko ltn. Pulgis Lumbis. Pasižymëjo 1919.06.06;

4. Nr. 1300-Generalinio štabo mjr. Jurgis Bobelis. Pasižymejjo 1919.06.18;

5. Nr. 1359-2-osios pėstininkų divizijos mjr. Bolius Giedraitis. Pasižymèjo 1919.09.06;

6. Nr. 1360-Karo sanitarijos skyriaus gydytojas kpt. Juozas Ūsas. Pasižymëjo 1919.09.23;

7. Nr. 1296-8-ojo pèstininkų Kauno kunigaikščio Vaidoto pulko 1tn. Andrius Klemas. Pasižymėjo 1919.08.24;

8. Nr. 1358-Generahnio štabo kapitonas Vaclovas Žadeika, karininkas cenzorius, pasižymėjęs 1919.11.23.

Pastaba: $1928 \mathrm{~m}$. vasario $10 \mathrm{~d}$. įsakyme kariuomenei Nr. $15 \S 9$ buvo paskelbta "Dalinai atitaisant 1923 m. Isakymo Kariuomenei 136 Nr. 2 \&, kapitoną Vaclovą Žadeiką (eil. Nr. 144) skaityti apdovanotu Vyties Kryžiaus ordenu ne kaip Generalio štabo karini cenzoriu, bet kaip 1-ojo didžiojo Lietuvos kunigaikščio Gedimino pulko karininką".

Už kovas su lenkais Suvalkijos fronte 1920 m. rugsëjo ir spalio mèn. 1-ojo laipsnio Vyties kryžiumi buvo apdovanoti:

9. Nr. 1265-5-ojo pėstininkų didžiojo Lietuvos kunigaikščio Kęs- 
tučio pulko kpt. Aleksas Bartkevičius. Pasižymėjo 1920.09.07;

10. Nr. 1266-5-ojo pėstininkų didžiojo Lietuvos kunigaikščio Kęstučio pulko vyr. 1tn. Leonas Šeštakauskas. Pasižymèjo 1920.09.03;

11. Nr. 1267-5-ojo péstininkų didžiojo Lietuvos kunigaikščio Kęstučio pulko ltn. Petras Saldukas. Pasižymèjo 1920.09.22;

12. Nr. 1295-8-ojo pėstininkų Kauno kunigaikščio Vaidoto pulko 1tn. Petras Kmieliauskas. Pasižymėjo 1920.09.23;

13. Nr. 1314-10-ojo péstininkų Marijampolès pulko mjr. Zenonas Gerulaitis. Pasižymèjo 1920.09.04;

14. Nr. 1341-1-ojo husaru pulko vyr. 1tn. Kazys Labutis. Pasižymèjo 1920.08.30;

15. Nr. 1346-1-ojo artilerijos pulko ltn. Julius Matulevičius. Pasižymèjo 1920.10.03;

16. Nr. 1353-Šarvuočiu auto diviziono vyr. 1tn. Julius Jakulis. Pasižymëjo 1920.09.13;

17. Nr. 1356-Aviacijos valdybos kpt. Stasys Jakštys. Pasižymejjo 1920.09.29;

18. Nr. 1357-Aviacijos valdybos vyr. 1tn. Vsevolodas Šenbergas. Pasižymėjo 1920.09.29.

Už kovas su želigovskininkais 2-ojo laipsnio Vyties kryžiumi buvo apdovanoti:

19. Nr. 81-2-ojo pėstininkų didžiojo Lietuvos kunigaikščio Algirdo pulko kpt. Eduardas Noreika. Pasižymėjo 1920.11.17;

20. Nr. 82-2-ojo pėstininkų didžiojo Lietuvos kunigaikščio Algirdo pulko vyr. 1tn. Juozas Andriūnas. Pasižymejjo 1920.10.21;

21. Nr. 91-Aviacijos valdybos vyr. 1tn. Jurgis Dobkevičius. Pasižymëjo 1920.11.07.

1-ojo laipsnio Vyties kryžiumi:

22. Nr. 1216-1-ojo pėstininkų didžiojo Lietuvos kunigaikščio Gedimino pulko pik. ltn. Petras Genys. Pasižymejjo 1920.10.16;

23. Nr. 1233-3-ojo péstininkų didžiojo Lietuvos kunigaikščio Vytauto pulko mjr. Adomas Drabatas. Pasižymèjo 1920.10.21;

24. Nr. 1234-3-ojo pėstininkų didžiojo Lietuvos kunigaikščio Vytauto pulko vyr. 1tn. Aleksas Urbonas. Pasižymèjo 1920.10.04;

25. Nr. 1233-ojo pèstininkų didžiojo Lietuvos kunigaikščio Vytauto pulko gydytojas vyr. 1tn. Borisas Strausburgas. Pasižymėjo 1920.10.09;

26. Nr. 1283-7-ojo pėstininkų žemaičių kunigaikščio Butegeidžio 
pulko kpt. Petras Baltrūnas. Pasižymėjo 1920.10.31;

27. Nr. 1284-7-ojo pėstininkų žemaičių kunigaikščio Butegeidžio pulko ltn. Zigmas Tiška. Pasižymèjo 1920.10.29;

28. Nr. 1285-7-ojo pėstininkų žemaičių kunigaikščio Butegeidžio pulko ltn. Vladas Kulvicas. Pasižymėjo 1920.10.21;

29. Nr. 1337-Baltgudžiu bataliono karininkas Borisas Blagoveščenskis. Pasižymejjo 1920.11.17;

30. Nr. 1338-Baltgudžių bataliono karininkas Grigorijus Majorovas. Pasižymejjo 1920.11.09;

31. Nr. 1362-Šiauliu stoties komendantūros vyr. 1tn. Nilas Dubrauskas. Pasižymėjo 1920.10.18;

Už kovas su lenkais neutraliojoje zonoje buvo apdovanoti 2 karininkai

2-ojo laipsnio Vyties kryžiumi:

32. Nr. 87-4-ojo pėstininkų Lietuvos karaliaus Mindaugo pulko

ltn. Kostas Dulksnys. Pasižymejjo 1923.02.24.

1-ojo laipsnio Vyties kryžiumi:

33. Nr. 1240-4-ojo pėstininkų Lietuvos karaliaus Mindaugo pulko 1tn. Kazys Petkevičius. Pasižymėjo 1923.02.24.

Už Klaipėdos krašto išvadavimą 1923 m. apdovanoti 4 karininkai 1-ojo laipsnio Vyties kryžiumi:

34. Nr. 1264-5-ojo pėstininkų didžiojo Lietuvos kunigaikščio Kęstučio pulko kpt. Povilas Strielnikas. Pasižymėjo 1923.01.15;

35. Nr. 1288-8-ojo pėstininku Kauno kunigaikščio Vaidoto pulko kpt. Mikas Kalmatavičius. Pasižymejjo 1923.01.15;

36. Nr. 1289-8-ojo pėstininkų Kauno kunigaikščio Vaidoto pulko ltn. Viktoras Burokevičius. Pasižymèjo 1923.01.15. (Apdovanotas po mirties);

37. Nr. 1366-Kauno komendantūros 1tn. Liudas Kaufmanas. Pasižymėjo 1923.01.15. ${ }^{65}$

${ }^{65}$ İsakymas kariuomenei. Nr. 136. § 2, 3. 1923 m. liepos 17 d.; Karys. 1923. Nr. 31. P. 364, Nr. 32. P. 378 (Pasinaudodamas įstatyme nurodytomis datomis Vyties Kryžiaus kavalierius su-skirsčiau i frontus, kuriuose jie pasižymėjo. Šiam suskirstymui panaudojau dr. Antano Ruk-šos darbą: Kovos dèl Lietuvos nepriklausomybès. Cleveland. 1981. T. 2. ir 1982. T.3.) 
Už pasižymėjimą kovose su lenkais Suvalkijos fronte minètu isakymu buvo apdovanoti keturi 5-ojo pesstininku pulko karininkai: leitenan-tai P. Saldukas (po mirties-žuvo $1920 \mathrm{~m}$. rugsèjo 22 d. ties Beržininkais) ir L. Šeštakauskas, kapitonai A. Bartkevičius ir P. Strielnikas. Taip buvo atsižvelgta i buvusio pulko vado mjr. K. Škirpos $1921 \mathrm{~m}$. sausio $27 \mathrm{~d}$. prašymą apdovanoti šio pulko pasižymėjusius karius.

8-ojo pėstininkų pulko Kauno kunigaikščio Vaidoto pulko ltn. Petras Kmieliauskas Vyties kryžiumi apdovanotas už kautynes su lenkais Suvalkijos fronte. Mūsų kariuomenès daliniams traukiantis ltn. P. Kmieliauskas parodè energija, šaltumą ir drąsą apsaugodamas savo dalinį nuo panikos, o jo turtą nuo sunaikinimo ${ }^{66}$.

Vienas iš apdovanotojų, 1-ojo husarų pulko vyr. 1tn. Kazys Labutis, kovose su lenkais ties Seinais $1920 \mathrm{~m}$. rugsėjo $22 \mathrm{~d}$. buvo lenkų apsuptas, bet greitai susiorientavo ir kovodamas pasitrauke i Augustavo miškus. Pereidamas frontą paèmé į nelaisvę lenkų sargybą ${ }^{67}$.

Už kovas su želigovskininkais 2-ojo laipsnio Vyties kryžiumi apdovanotas kpt. Eduardas Noreika pasižymėjo 1920 m. lapkričio 17 d., kai prie Giedraičiu sunaikino šarvuoti. Be to, kpt. E. Noreikos vadovaujamas batalionas pasižymėjo ir spalio 30,31 dienomis, kovodamas ŽelvosGiedraičių rajone ${ }^{68}$.

Vyr. ltn. Juozas Andriūnas apdovanotas po mirties už pasižymèjimą 1920 m. spalio 21 d. Žuvo spalio 31 d. netoli Karklynès kaimo prie Giedraičiuc, kai jo vadovaujama 9-oji kuopa atakavo želigovskininkus ${ }^{69}$.

Ltn. Zigmas Tiška apdovanotas po mirties. 1920 m. lapkričio $17 \mathrm{~d}$. Z. Tiškos vadovaujama kuopa vadavo Motiejūnų kaimą. Kautynių metu Z. Tiška buvo sunkiai sužeistas ir miré ${ }^{70}$.

Atskirojo Baltgudžių bataliono štabskapitonas Borisas Blagovieščenskis (Baltgudžiu batalione galiojo Rusijos kariuomeneje igyti laipsniai) apdovanotas 1-ojo laipsnio Vyties kryžiumi už pasižyméjimą 1920 m. lapkričio 17 d. prie Žiešviškio kaimo ${ }^{71}$.

\footnotetext{
${ }^{66}$ Karys. 1940 m. Nr. 21. P. 552

${ }^{67}$ Raštikis S. Lietuvos likimo keliais. 1996. T. IV. P. 85

${ }^{68}$ Rukša A. Kovos dèl Lietuvos nepriklausomybès 1982. T. III. P. 314-316, 340-342

${ }^{69}$ Rukša A. Kovos dèl Lietuvos nepriklausomybès 1982. T. III. P. 316

${ }^{70}$ Kardas. 1934 m. Nr. 13. P. 252; Karys. 1939 m. Nr. 26. P. 776

${ }^{71}$ CVA F 930. Ap. 5. B. 269. L. 11, 13, 14
} 
Kapitonas Mikas Kalmatavičius (Mykolas Kalmantas) Vyties kryžiumi buvo apdovanotas už nuopelnus prijungiant Klaipèdą prie lietu$\operatorname{vos}^{27}$.

Leitenantas Viktoras Burokevičius apdovanotas po mirties (žuvo 1923 m. sausio 15 d. šturmuodamas Klaipėdos prefektūrą) ${ }^{73}$.

\section{0-1926 M. APDOVANOTIEJI ANTROSIOS RŪŠIES VYTIES KRYŽIUMI}

Šis apdovanojimas kai kuriuose Prezidento pasirašytuose įsakymuose vadinamas Vyties kryžiumi be kardu arba antrosios rūšies Vyties kryžiaus ordinu. Iš pradžių antrosios rūšies Vyties kryžiumi be kalavijų, skirtu užnugario darbuotojams pagerbti, apdovanoti neskubèta. Todèl pirmą kartą juo apdovanota tik $1920 \mathrm{~m}$. balandžio 7 dieną. Vyties kryžiumi be kardų apdovanotas 2-ojo péstininkų didžiojo Lietuvos kunigaikščio Algirdo pulko vyr. 1tn. Vladas Gricius. Prezidento A. Smetonos įsakymu už pasižymèjimą mūšiuose su priešu Vyties kryžiumi apdovanotų karininku ir kareiviu grupejje vyr. ltn. V. Gricius buvo vienintelis pagerbtas 1-ojo laipsnio Vyties kryžiumi be kardu ${ }^{74}$.

Lietuvos karininkijai reikejjo drąsos ir sumanumo ne tik atviroje kovoje su priešu fronte. Lietuvos nepriklausomybei pavojus grèsè ir šalies viduje. Vienas iš pagrindinių po Pirmojo pasaulinio karo atsikūrusios Lenkijos politinių siekimų buvo prijungti prie Lenkijos Lietuvą. Lietuvos vyriausybei nuversti lenkai organizavo slaptas organizacijas. Stipriausia lenku organizacija-P O W (Polska Organizacja Wojskowa)-buvo įkurta Kaune. 1919 m. rugpjūčio 27-28 d. ji pradejo diversinius veiksmus ir sąmokslą prieš Lietuvos valstybę. P O W sąmokslui išaiškinti daug padare Vilniaus lietuviai Boleslovas Stadzevičius, Mykolas Biržiška, Petras Vrubliauskas, Aldona Čarneckaitè. Karininko Jurgio Bobelio vadovaujami kariai 1919 m. rugsejjo 21 d. surado P O W archyvą, kuri iteikè Ypatingajai

\footnotetext{
${ }^{72}$ Kavaliauskas V Klaipėdos išvadavimo medalis //Kolekcija Nr. 5. 1998. P. 33 - 34; Juodagalvis

J. Toks buvo pulkininkas Mykolas Kalmantas//Gimtinè. 1997 m. rugpjūčio 1-31 d. Nr. 8. P. 1.

${ }^{73}$ Ardzijauskaitė D. Vilkaviškio krašto kariai savanoriai// Gimtinè. 1997 m. spalio 1-31 d. Nr. 10. P. 2 .

${ }^{74}$ Isakymas kariuomenei Nr. 300. §1. 1920 m. balandžio 14 d.
} 
tardymo komisijai. Archyvinė medžiaga padèjo galutinai likviduoti P O W organizacija, taip pat pateikti kaltinimus jos nariams ${ }^{75} .1920 \mathrm{~m}$. gegužès 13 d. Prezidento A. Smetonos įsakymu už darbą vokiečiu okupacijos metu ir veiklą išaiškinant P O W Generalinio štabo vyr. ltn. Jurgis Bobelis apdovanotas 1-ojo laipsnio Vyties kryžiumi be kardų ${ }^{76}$. Vyr. ltn. Jurgis Bobelis buvo antras asmuo, apdovanotas antrosios rūšies 1-ojo laipsnio Vyties kryžiumi. Lietuvos kariuomenès sèkmę frontuose lèmè ir jos aprūpinimas maistu, apranga, ginkluote, sanitarinèmis priemonèmis. Tą darbą dirbo intendantūros tarnybos. Karo nualintame krašte aprūpinimo klausimus igyvendinti buvo nelengva. $1920 \mathrm{~m}$. gegužès 25 d. įsakymu Prezidentas A. Smetona pažymèjo Vlado Grudzinsko nuopelnus-"UŽ sąžiningą ir naudingą pasidarbavimą Tiekimų srityje mūsų Valstybès naudai Armijos Intendanto Padejejejas karo valdininkas Vladas Grudzinskas apdovanojamas 1-ojo laipsnio Vyties Kryžium be kardų" " .

V. Grudzinskui intendantūros darbas buvo geras žinomas - Rusijos kariuomeneje jis buvo 10-osios armijos Ūkio dalies viršininko pagalbininku, vèliau-4-osios armijos Ūkio dalies viršininku. Lietuvos kariuomenèję 1919 m. gegužès $21 \mathrm{~d}$. V. Grudzinskas buvo paskirtas Tiekimu skyriaus Kanceliarijos viršininku, o nuo liepos $21 \mathrm{~d}$. iki rugpjūčio $11 \mathrm{~d}$. vadovavo Tiekimų skyriui ${ }^{78}$.

1920 m. liepos mėnesi Raudonajai armijai stumiant lenku kariuomenę iš Vilniaus krašto, pasirūpinta atkurti Vilniaus miesto ir apskrities komendantūrą. Ji prižiūrèjo tvarką mieste. $1920 \mathrm{~m}$. spalio $8 \mathrm{~d}$. generolui L. Želigovskiui pradejjus žygi $i$ Vilnių, komendantūra pasitraukè iš miesto ${ }^{79}$.

1920 m. lapkričio 13 d. Respublikos Prezidento isakymu "Už pasidarbavimą Tèvynès labui, kuriant Vilniaus miesto ir apskrities komendantūrą" pirmasis komendanto padejejjas ltn. Vladas Petronaitis buvo apdovanotas 1-ojo laipsnio Vyties kryžiumi be kardų ${ }^{80}$.

\footnotetext{
${ }^{75}$ Rukša A. Kovos dèl Lietuvos nepriklausomybès. Cleveland. 1981. T. II. P. 221-264

${ }^{76}$ Lietuvos kariuomenei ịsakymas Nr. 335. 1920 m. gegužès 21 d. ; Kariškių žodis. 1920. Nr. 23 
1921 m. birželio 10 d. krašto apsaugos ministras isakè Generalinio štabo viršininkui, Vietinès kariuomenès brigados vadui, Armijos teismo pirmininkui, Sanitarijos vadybos viršininkui ir Veterinarijos skyriaus viršininkui skubiai pristatyti kandidatu pavardes "Vyties Kryžiumi II rūšies (be kalaviju) apdovanojimui" 81 .

Gavusi i̇sakymą, Vietinès kariuomenès brigada krašto apsaugos ministrui atsiunte net 22 kandidatu apdovanoti antrosios rūšies Vyties kryžiumi "dovanų lapus": 10 karininkų, 5 karo valdininku ir 7 kareivių ${ }^{82}$. Kitos kariuomenès dalys taip pat neatsiliko.

Tarp siūlomų apdovanoti karininkų buvo Panevėžio miesto ir apskrities komendantas kapitonas Tadas Chadakauskas. T. Chadakausko 1921 m. liepos 2 d. "Dovanu lape" rašoma: "Pasižymi ypatingu darbštumu, energija, sumanumu ir sažziningumu atliekant laike 2 metu savo pareigas" 83 .

Vieno kandidato-Kauno miesto ir apskrities Karo komendanto kapitono Jono Mačiulaičio-"Dovanų lape" parašyta: "Pasižymi ypatingu darbštumu ir sąžiningumu atliekant savo pareigas". Kpt. J. Mačiulaitis pristatė apdovanoti Vyties kryžiumi savo pavaldini kapitoną Vladą Braziulevičiu pažymėdamas: "Kapitonas Braziulevičius tarnaudamas man pavestoje karo komendantūroje nuo $1919 \mathrm{~m}$. spalio 24 d. atsižymėjo sąžiningu pareigu ejjimu ir ypatingu darbštumu kaip mano Padejjëjas, Pulko Teismo ir Karo lauko Teismo Pirmininkas ir kaipo kareivių kultūrinimo darbuotojas" ${ }^{84}$.

Dar iki ministro i̇sakymo pristatyti kandidatų apdovanoti sąrašus, 1921 m. gegužès 1 d. Armijos teismo pirmininkas pulkininkas Petras Šniukšta krašto apsaugos ministrui nusiųstame raporte pažymejjo, kad 1921 m. liepos 7 d. sukanka dveji metai kaip veikia Armijos teismas. Nuo pat Armijos teismo isteigimo pradžios jame dirba: "... Jo Pirmininkas pulkininkas Šniukšta, nuolatiniai nariai pulkininkas leitenantas Vimeris ir majoras Liandsbergis, gan ilgą laiką - Valstybès Gynejjas Kapitonas Zaikauskas ir jo padèjējas kapitonas Papečkys. Ačiū šiu penkių asmenu

\footnotetext{
${ }^{81}$ CVA F 384. Ap. 2. B. 231. L. 2

${ }^{82}$ CVA F 384. Ap. 2. B. 231. L. 7

${ }^{83}$ CVA F 384. Ap. 2. B. 231. L. 14-15

${ }^{84}$ CVA F 384. Ap. 2. B. 231. L. $18-21$
} 
darbštumui Armijos Teismas igijo visuomenès pasitikèjimą ir pasižymejjo nuolatine nenuilstama kova su nusikaltimais. Armijos Teismo darbuotojai dirba savo sunkų darbą dieną ir naktí. Jų jègos taip įtemptos darbštume, kad vyriausybe pati privalo juos pažymèti." Raporto pabaigoje Armijos Teismo pirmininkas pik. P. Šniukšta siūlo visus minimus asmenis apdovanoti Vyties Kryžiais ${ }^{85}$.

Nors kandidatų sąrašai buvo parengti, bet apsiribota tiktai kelių asmenų nuopelnų ivertinimu. Didelis apdovanotujų skaičius galëjo sukelti fronto kariu Vyties kryžiaus su kalavijais kavalierių nepasitenkinimą. 1921 m. liepos 14 d. einančio Respublikos Prezidento pareigas Steigiamojo Seimo Pirmininko A. Stulginskio įsakymu už pavyzdingą dvejų metų tarnybą Lietuvos kariuomenès karo isstaigose ir gerą darbo organizavimą antrosios rūšies 1-ojo laipsnio Vyties kryžiumi apdovanoti: Armijos teismo pirmininkas pik. Petras Šniukšta (Vyties kryžiumi Nr. 11), Karo sanitarijos vadybos viršininko padējëjas gydytojas pik. Vladas Ingelevičius (Vyties kryžiumi Nr. 12) ir buvęs Inžinerijos skyriaus viršininkas mjr. Balys Sližys (Vyties kryžiumi Nr. 13). "Už pravedimą kaltinamų "P. O. W." organizacijų bylos" Armijos teismo valstybès gynëjo padejjëjas kapitonas Juozas Papečkys (Vyties kryžiumi Nr. 14), "už sutvarkymą revizijos ir kontrolès darbo prie Tiekimų Vadybos"-Kontrolès skyriaus viršininko padejejjas karo valdininkas Viktoras Tarasevičius ( Vyties kryžiumi Nr. 15) "Už susekimą keletos priešvalstybinių organizacijų"-generalinio štabo Žvalgybos skyriaus viršininkas karo valdininkas Mikas Lipčius (Vyties kryžiumi Nr. 16) ${ }^{86}$.

Kandidatai gauti apdovanojimus kapitonai J. Mačiulaitis ir V. Braziulevičius buvo apdovanoti 1926 m., o kapitonas T. Chadakauskas-1929 m.

$1921 \mathrm{~m}$. gruodžio 30 d. Respublikos Prezidento isakymu Tiekimu Vadybos Ūkio dalies viršininkas karo valdininkas Vytautas Augustauskas už ypatingą pasižymėjimą tvarkant kariuomenès ūki buvo apdovanotas antrosios rūšies 1-ojo laipsnio Vyties kryžiumi. ${ }^{87}$

Dideli darbą atliko V. Augustauskas organizuodamas pirmojo lietuviško apdovanojimo-Vyties Kryžiaus-gamybą ir paskirstymą Vyties kryžiaus kavalieriams.

\footnotetext{
${ }^{85}$ CVA F 384. Ap. 2. B. 231. L. 3, Kavaliauskas V Už nuopelnus Lietuvai. V. 2001. P. 75

${ }^{86}$ Isakymas kariuomenei Nr. 168. § 1, 2, 3, 4. 1921 liepos $23 \mathrm{~d}$.

${ }^{87}$ Isakymas kariuomenei. Nr. 3. § 3. P. 1. 1922 m. sausio 2 d.
} 
1922 m. vasario 16 d. ịsakymu, kuri pasirašè einantis Respublikos Prezidento pareigas Steigiamojo Seimo Pirmininkas A. Stulginskis ir krašto apsaugos ministras mjr. inžinierius B. Sližys, antrosios rūšies 1-ojo laipsnio Vyties kryžiumi buvo apdovanotas laikinai einantis kariuomenès vado pareigas gen. ltn. Juozas Kraucevičius. Isakymas skelbè: "Laikinai einantį Kariuomenès Vado pareigas Aviacijos Viršininką generolą leitenantą Juozą Kraucevičių už pavyzdingą sutvarkymą ir išplètojimą mūsų aviacijos, kuri, dèka jo energijai, jo pastangoms, dabar sudaro žymią pajęgą ir reikalui esant, pilnai sugebès atlikti jai skiriamą didelès svarbos vaidmeni bendrame mūsų kariuomenès veikime, taipgi už jo neužmirštiną pasidarbavimą kariuomenès valdymo srityje, už ta, kad jis savo atsidavimu vadovavimo darbams, savo nenuilstamu rūpesniu labai daug prisidejjo prie išvystymo mūsų kariuomeneje dabar matomos gražios vidujinès tvarkos ir pavyzdingos vienijančios drausmès, taigi, už tuos visus atsakomingus ir gražiai atliktus darbus apdovanoju ji 2-os rūšies 1-ojo laipsnio "Vyties Kryžiumi" (21 Nr.)" ${ }^{188}$.

1922 m. spalio 7 d. einančio Respublikos Prezidento pareigas A. Stulginskio įsakymu Nr. 105 generalinio štabo Žvalgybos skyriaus Kontržvalgu dalies viršininkas karo valdininkas Jonas Polovinskas ir karo valdininkas Kazys Budrevičius už darbštumą ir energiją žvalgybos srityje buvo apdovanoti antrosios rūšies 1-ojo laipsnio Vyties kryžiumi ( J. Polovinskasnuo Klaipėdos sukilimo Jonas Budrys -Nr. 23, K. Budrevičius -Nr. 24) ${ }^{89}$.

1923 m. liepos 17 d. i̇sakymu Vyties kryžiumi be kardu (Nr. 26) buvo apdovanotas 2-ojo ulonu pulko kapelmeisteris karo valdininkas Jonas Braunas. Apdovanojimo nusipelné už parodytą veiklumą ir darbštumą organizuojant pulko orkestrą ir už kompozicijų karo orkestrui sukūrimą ${ }^{90}$.

1923 m. gruodžio 27 d. buvo paskelbta, kad "apdovanojimai II-ros rūšies Vyties Kryžiaus Ordenu" ivyksta du kartus per metus: sausio 1 dieną ir gegužès 15 dieną". 1923 m. gruodžio 28 d. krašto apsaugos ministras majoras inžinierius B. Sližys ir generalinio štabo viršininkas Lietuvos Radus-Zenkavičius peržiūrèti ir išspręsti apdovanojimo Vyties kryžiumi klausimams sudarė naują Vyties kryžiaus ordino tarybą. Jos pirmininku

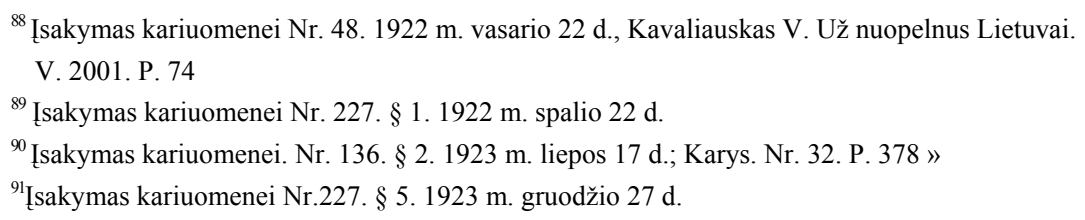


paskyrè laikinai einanti kariuomenès inspektoriaus pareigas generolą $\mathrm{J}$. Kubiliu, nariais - Generalinio štabo viršininko antraji padejejją pik. ltn. A. Zubri ir 3-iojo pėstininku pulko vadą pik. ltn. V. Šaudzi. Tarybai buvo isakyta pradèti darbą $1923 \mathrm{~m}$. gruodžio $28 \mathrm{~d}$. 16 val. ${ }^{22}$ Ši Taryba apdovanojo tik antrosios rūšies Vyties kryžiumi. Po Vyties kryžiaus ordino tarybos $1923 \mathrm{~m}$. gruodžio 28 d. posėdžio, Respublikos Prezidento A. Stulginskio 1924 m. sausio 1 d. i̇sakymu Nr. 133, už "Aukštujų Karininkų didžiojo Lietuvos Kunigaikščio Vytauto Kursų" suorganizavimą ir jų vedima, už Karo Mokslo skyriaus ikūrima, kuriame jo pastangomis buvo išleista visa eilè karo statutu, išdirbta ir jau igyvendinta Lietuvos kariuomeneje nauja karo doktrina-generolas Radus - Zenkavičius apdovanotas antrosios rūšies 1-ojo laipsnio Vyties Kryžiumi (Nr. 29) ${ }^{93}$.

1923 m. pabaigoje i atsargą išèjo Lietuvos krašto apsaugos ministras gen. Itn. Juozas Stanaitis. J. Stanaitis buvo vienas iš Klaipedos sukilimo iniciatorių. Jo nuopelnai buvo deramai ivertinti. Respublikos Prezidentas 1923 $\mathrm{m}$. gruodžio $31 \mathrm{~d}$. issakymu gen. 1tn. J. Stanaičiui už ištikimą tarnybą Tẻvynei pareiškè padèką, apdovanojo antrosios rūšies 1-ojo laipsnio Vyties kryžiumi (Nr. 34) ir suteikè teisę išèjus i atsargą dèvèti karinę uniformą. $1926 \mathrm{~m}$. vadovaujantis "Laikinosiomis Vyties Kryžiaus ordeno apdovanojimo taisyklėmis" buvo apdovanojama ne Vyties kryžiumi, bet Vyties kryžiaus ordinu. Tačiau iš tikrujų ir toliau šio apdovanojimo kavalieriams buvo įteikiami 1920 $\mathrm{m}$. vasario $3 \mathrm{~d}$. ịstatymu patvirtintas Vyties kryžius. Prieš atsisveikindamas su Lietuvos kariuomene, palikdamas Lietuvos Prezidento postą A. Stulginskis apdovanojo didelę grupę Lietuvos karininkų. Parengiamaji darbą atrenkant kandidatūras atliko Vyriausiasis kariuomenès štabas.

1926 m. gegužès 31 d. einantis Generalinio štabo valdybos viršininko pareigas gen. ltn. Jurgis Kubilius raporte Vyriausiojo štabo viršininkui pristate apdovanoti Generalinio štabo karininkus: Susisiekimo skyriaus viršininką pik. ltn. Joną Mačiulaiti, Mobilizacijos skyriaus viršininką pik. ltn. Vaclovą Griganavičių, Operacijų skyriaus kapitoną Juozą Krikščiūną, Informacijos skyriaus vyr. 1tn. Juozą Matusaiti ir Mobilizacijos skyriaus karo vald. Gustavą Petrikaiti.

${ }^{92}$ CVA F. 930 . Ap. 5. B. 1396 a. L. 16

${ }^{93}$ Krašto apsaugos ministerio i̇sakymas Nr. 3. § 1.1924 m. sausio 1 d., Kavaliauskas V. Už

nuopelnus Lietuvai. V. 2001. P. 74

${ }^{94}$ Isakymas kariuomenei Nr. 235. § 1. 1923 m. gruodžio 31 d., Kavaliauskas V. Už nuopelnus Lietuvai. V. 2001. P.74 
Apdovanoti Vyties kryžiumi 6 kandidatus pristate KAM Administracijos valdyba: KAM Kanceliarijo viršininką adm. kpt. Kazi Stebuli, Rikiuotès skyriaus Sudèties ir bendrosios dalies vedèją majorą Andriu Pridotka, Rikiuotès skyriaus Pensiju dalies vedèją kpt. Juozą Katinską, Rikiuotès skyriaus Laipsnių ir dovanų dalies vedèją karo valdininką Boliu Bobeli, Ūkio skyriaus iždininką karo valdininką Kazị Penčylą ir Centrininio kariuomenès archyvo viršininką karo valdininką Joną Laucevičiu. ."

1926 m. birželio 7 d. aktu Nr. 161 Lietuvos Prezidentas Antanas Stulginskis, atsižvelgdamas i Vyties kryžiaus ordino tarybos nutarimą ir Krašto apsaugos ministro teikimą, už uolią ir sąžiningą kelerių metų tarnybą antrosios rūšies 1-ojo laipsnio Vyties kryžiaus ordinu apdovanojo 33 Lietuvos karininkus. Issakyme buvo pažymèti šių ordinų numeriai. Tai yra ne kas kita, o Vyties kryžiaus numeravimo tęsinys. Prezidentas apdovanojo:

Pèstininkus:

1.Vyriausiojo štabo Susisiekimo skyriaus viršininką pulkininką leitenantą Joną Mačiulaiti (Nr. 31),

2.1 karo apygardos štabo pulkininką leitenantą Juozą Skoruli (Nr. $33)$, (Nr. 37),

3. III karo apygardos viršininką pulkininką leitenantą Joną Griciu (Nr.38),

4. III karo apygardos štabo pulkininką leitenantą Liudą Butkevičiu

5. 1-ojo pėstininkų didžiojo Lietuvos kunigaikščio Gedimino pulko kapitoną Albiną Čepauską (Nr.39),

6. 2-ojo pèstininkų didžiojo Lietuvos kunigaikščio Algirdo pulko majorą Bronių Ivanauską (Nr.40),

7. 3-iojo pėstininkų didžiojo Lietuvos kunigaikščio Vytauto pulko majorą Andrių Purpetri (Nr.41),

8. 4-ojo péstininkų Lietuvos karaliaus Mindaugo pulko vadą pulkininką Praną Tamašauską (Nr. 42),

9. 4-ojo pėstininkų Lietuvos karaliaus Mindaugo pulko vyr. leitenantą Praną Bronevičiu (Nr. 43),

10. 5-ojo pèstininkų didžiojo Lietuvos kunigaikščio Kęstučio pul ko vyr. leitenantą Jurgị Brusoką (Nr. 44), 
11. 6-ojo pėstininkų Pilènų kunigaikščio Margio pulko majorą Aleksandrą Svilą (Nr. 45),

12. 9-ojo pėstininkų Lietuvos kunigaikščio Vytenio pulko vadą pulkininką leitenantą Vincą Vitkauską (Nr. 46),

13. Karo mokyklos viršininką generolą leitenantą Joną GalvydįBykauską (Nr. 47)

14. Kauno igulos komendantą pulkininką leitenantą Vladą Braziulevičiu (Nr. 48),

15. Kauno igulos komendantūros vyr. leitenantą Kostą Rudaiti (Nr. 49),

16. Kariuomenès Intendantūros majorą Vincą Butauską (Nr. 50),

17. Atsargos kapitoną Mykolą Kvintą (Nr. 51);

Kavalerijos karininkus:

18. 1-ojo husarų pulko vyr. leitenantą Juozą Bačkų (Nr. 52),

19. 2-ojo ulonu pulko vyr. leitenantą Juozą Ugianski (Nr. 53);

Artilerijos karininką

20. 4-ojo artilerijos pulko majorą Jackų Bani (Nr. 54);

Inžinerijos karininką

21. Technikos pulko kapitoną Jokūbą Baubliauską (Nr. 55);

Aviacijos karininkus:

22. vyr. leitenantą Antaną Gaveli (Nr. 56),

23. vyr. leitenantą Viktorą Reimontą (Nr. 57);

Administracijos Tarnybos pareigūnus:

24. Krašto apsaugos ministerijos Kanceliarijos viršininką kapitoną Kazị Stebuli (Nr. 58),

25. Vyriausiojo štabo Rikiuotès skyriaus karo valdininką Bolių Bobeli (Nr. 59), (Nr.60),

26. Vyriausiojo štabo Ūkio skyriaus karo valdininką Kazị Penčilą

27. Kariuomenès Intendantūros karo valdininką Stasị Krukauską (Nr.61),

28. Atsargos karo valdininką Liudą Girą (Nr.62);

Sanitarijos Tarnybos karininkus:

29. Karo ligoninès viršininką pulkininką Kazị Oželị (Nr.63),

30. Karo ligoninès pulkininką Petrą Radzvicką (Nr.64),

31. Karo ligoninès pulkininką leitenantą Baltrų Atkočiūną (Nr.65),

32. Mokomosios baterijos majorą Liną Janulioni (Nr.67), 
33. Atsargos majorą Vincą Kanauką (Nr.68).

Krašto apsaugos ministro teikimu už uolią ir sąžiningą tarnybą antrosios rūšies 2-ojo laipsnio Vyties kryžiaus ordinu (Nr.15)buvo apdovanotas kariuomenès teismo pirmininkas Teismo tarnybos generolas leitenantas Petras Šniukšta ${ }^{96}$. P. Šniukšta buvo vienintelis Lietuvos pilietis, apdovanotas dviem antrosios rūšies Vyties kryžiais.

1926 m. spalio 18 d. krašto apsaugos ministro pulkininko ltn. J. Papečkio isakymu Nr. 97 Vyties kryžiaus ordinu apdovanojimo klausimams svarstyti buvo sudaryta Laikinoji Vyties kryžiaus ordino taryba, kurią sudare Vyties kryžiaus ordino kavalieriai: pirmininkas generolas Silvestras Žukauskas, nariai: pik. Aleksandras Jakaitis, pik. Vincas Šaudzis, pik. 1tn. Jonas Petruitis ir pik. 1tn. Motiejus Pečiulionis.

Vyties kryžiaus ordino tarybai buvo pavesta savo uždavinius atlikti vadovaujantis apdovanojimo Vyties kryžiaus ordinu taisyklèmis ${ }^{97}$. Ši taryba spejo apdovanoti tiktai vieną karininką, nes $1927 \mathrm{~m}$. buvo įsteigtas Vyties kryžiaus ordinas.

1926 m. lapkričio 30 d. Respublikos Prezidentas Kazys Grinius Laikinosios Vyties kryžiaus ordino tarybos nutarimu ir Krašto apsaugos ministerijos teikimu "už uolų ir sąžiningą pasidarbavimą karo mokslo literatūroje" antrosios rūšies 1-ojo laipsnio Vyties kryžiaus ordinu Nr. 72 apdovanojo 2-ojo pėstininkų didžiojo Lietuvos kunigaikščio Algirdo pulko majorą Vytautą Steponaititi.

Tai buvo paskutinis apdovanojimas Vyties kryžiumi. Šio apdovanojimo tradicijas tęsė 1927 m. ịsteigtas Vyties kryžiaus ordinas, o 1930 m.-Vyčio kryžiaus ordinas bei Vyčio kryžius.

\section{VYTIES KRYŽIAUS KAVALIERIAI KARININKAI ATSIIMA SAVO APDOVANOJIMUS}

1920 m. vasario 3 d. Prezidentui patvirtinus Vyties kryžiu, buvo numatyta kiekvieną apdovanojimą pažymèti numeriu. Tačiau vėlesni apdovanojimai nebuvo numeruojami, nes dar nebuvo pagamintas pats ženklas. Pagaliau suderinus Vyties kryžiaus gamybos organizacinius klausimus buvo parengtas ir numeriu sarašas. $1921 \mathrm{~m}$. liepos $4 \mathrm{~d}$. buvo paskelbtas krašto apsaugos ministro J. Šimkaus isakymas, kuriame buvo surašyti visi Vyties kryžių numeriai, kuriuos turèjo gauti Vyties kryžiaus kavalieriai.

\footnotetext{
${ }^{96}$ Krašto apsaugos ministerio įsakymas Nr. $55 \S 1,2.1926$ m. birželio $7 \mathrm{~d}$.

${ }^{97}$ Krašto apsaugos ministerio isakymas Nr. 97 . § 3.1926 m. spalio $18 \mathrm{~d}$.

${ }^{98}$ Krašto apsaugos ministerio issakymas Nr. 105. 1926 m. gruodžio 15 d. Respublikos Prezidento aktas Nr. 505
} 
Pirmieji Vyties kryžiaus numeriai buvo paskirti kareiviams. Pirmosios rūšies 1-ojo laipsnio Vyties kryžiu Nr. 1 gavo 1-ojo pėstininku didžiojo Lietuvos kunigaikščio Gedimino pulko eilinis Juozas Aliulis. Tik "Nr. 8" atiteko vienam pirmuju žuvusiam Panevėžio bataliono karininkui Jonui Nastopkai. "Nr. 1000" gavo 7-ojo pėstininku pulko kapitonas Vincas Vitkauskas. 2-ojo laipsnio "Nr. 1" gavo 1-osios Baltgudžių kuopos būrininkas Afana Šule, o "Nr. 3"-2-ojo péstininku pulko karininkas Antanas Zubrys. 2-osios

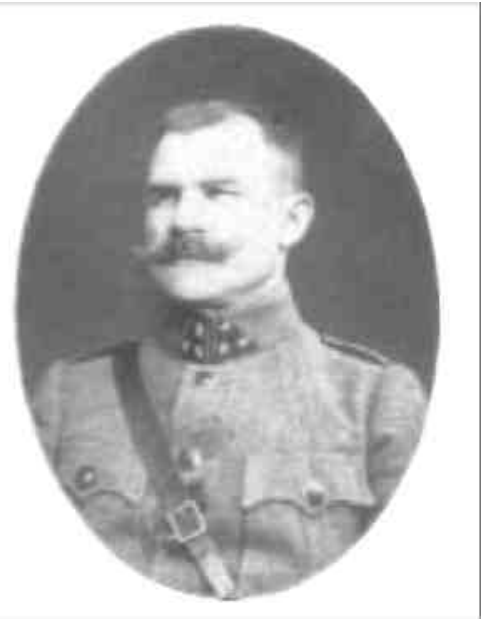

rūšies Vyties kryžiaus "Nr. 1" gavo Bataliono vadas kpt. Kazys Mackevičius karininkas Jurgis Bobelis ${ }^{\text {}}$. su 1-ojo ir 2-ojo laipsnių vyties kryžiu Vèlesniuose Prezidento isakymuose kaspinèliais munduro sagu kilpose. jau buvo pažymimas apdovanojimo, Atspindžiai. $1921 \mathrm{~m}$. birželio mèn. kuri gaudavo Vyties kryžiaus kavalierius, numeris.

Organizuoti Vyties kryžių gamybą buvo pavesta Krašto apsaugos ministerijos Tiekimų vadybos Ükio daliai. Vyties kryžius iš vario ir bronzos gamino Karo invalidų komiteto graverių dirbtuvès. Iš pradžių Vyties kryžius turejo labai daug variantu, nes skyrèsi ne tik metalo ir emalio rūšys, bet ir spaudai. V. Kavaliausko duomenimis pirmieji Vyties Kryžiaus ženklai buvo pagaminti $1920 \mathrm{~m}$. vasarą ${ }^{100}$.

1921 m. rugpjūčio mėnesi KAM Tiekimu vadybos Ūkio dalis pradejo išduoti pirmuosius pagamintus Vyties kryžius. Vieni iš pirmujų savo apdovanojimus atsiėmė 7-asis pėstininkų žemaičių kunigaikščio Butegeidžio pulkas. 95 vienetus 1-ojo laipsnio Vyties kryžiu Tiekimų vadybos Ūkio dalis pulkui perdavè $1921 \mathrm{~m}$. rugpjūčio $1 \mathrm{~d} .{ }^{101}$,

\footnotetext{
${ }^{99}$ Isakymas kariuomenei Nr. 150. § 1. $1921 \mathrm{~m}$. liepos 4 d.

${ }^{100}$ Kavaliauskas V. Estijos, Latvijos, Lietuvos ordinai ir medaliai 1918-1940. V. 1997. P. 54, Kavaliauskas V. Už nuopelnus Lietuvai. V. 2001. P. 53
}

${ }^{101}$ CVA. F929 Ap.9. B. 354. L. 113

137 
rugpjūčio 11 d. 33 vienetus -8-ajam pėstininkų Kauno kunigaikščio Vaidoto pulkui ${ }^{102}$.

1921 m. rugpjūčio 12 d. Aviacijos viršininkas gen. ltn. J. Kraucevičius igaliojo ltn. Juozą Pranckevičių iš Tiekimų vadybos Ūkio dalies paimti Vyties kryžius, skirtus leitenantams J. Dobkevičiui (Nr. 945), J. Pranckevičiui (Nr. 946) ir J. Kumpiui (Nr. 947) ${ }^{103 .}$

$1921 \mathrm{~m}$. rugpjūčio $12 \mathrm{~d}$. buvo išduoti 218 vienetai 1-ojo laipsnio Vyties kryžių 2-ajam didžiojo Lietuvos kunigaikščio Algirdo pulkui ${ }^{104}$.

1921 m. rugpjūčio 13 d. išduota 119 pirmosios rūšies Vyties kryžiu 6-ajam pėstininkų Pilènų kunigaikščio Margirio pulkui, 2-ojo laipsnio Vyties kryžiu 6-asis pulkas tuomet dar negavo ${ }^{105}$.

1921 m. rugpjūčio 13 d. Ūkio dalis išdave 31 Vyties kryžius artilerijos brigadai ${ }^{106}$.

1921 m. rugpjūčio 17 d. iš Ūkio dalies buvo paimti 155 Vyties kryžiai 4-ajam pèstininkų Lietuvos karaliaus Mindaugo pulkui ${ }^{107}$.

1921 m. rugpjūčio menesi 37 vienetus pirmosios rūšies 1-ojo laipsnio Vyties kryžius 5-ajam didžiojo Lietuvos kunigaikščio Kęstučio pulkui paėmè ltn. Karolis Markevičius. Apdovanojimas buvo skirtas ir ltn. Stasiui Raštikiui (Nr. 554) ${ }^{108}$.

1921 m. rugsèjo 12 d. buvo išduoti 209 pirmosios rūšies 1-ojo laipsnio Vyties kryžiai, kurie turejo būti itteikti 1-ojo pėstininkų didžiojo Lie-

\footnotetext{
${ }^{102}$ CVA. F 929. Ap. 9. B. 354. L. 118

${ }^{103}$ CVA. F 929. Ap. 9. B. 354. L. 94

${ }^{104}$ CVA. F 929. Ap. 9. B. 354. L. 124-125

${ }^{105}$ CVA. F 929. Ap. 9. B. 354. L. 46-48

${ }^{106}$ CVA. F 929. Ap. 9. B. 354. L. 26

${ }^{107}$ CVA. F929. Ap. 9. B. 354. L. 106

${ }^{108}$ CVA. F929. Ap. 9. B. 354. L. 40
} 
tuvos kunigaikščio Gedimino pulko kareiviams ir karininkams. Šiam pulkui perduota ir 17 vienetu pirmosios rūšies 2-ojo laipsnio Vyties kryžių. Juos turejjo gauti ir karininkai Kazys Ladyga (Nr. 46), Povilas Dundulis (Nr. 17), Stasys Marcinkevičius (Nr. 18), mjr. Vladas Skorupskis (Nr. 60), mjr. Vincas Šaudzis(Nr. 54) ${ }^{109}$.

1921 m. rugsẻjo 13 d. 38 Vyties kryžiai buvo išduoti 3-iajam didžiojo Lietuvos kunigaikščio Vytauto pulkui ${ }^{110}$.

Atskirujų karinių vienetų karininkai patys rūpinosi atsiimti savo apdovanojimus. $1921 \mathrm{~m}$. rugsèjo 23 d. Operacijų skyriaus viršininkas kpt. Balys Jakutis kreipèsi i Tiekimų vadybos Ūkio skyriaus viršininką: "Prašau Tamstos paredymo išduoti priklausantị man Vyties Kryžiu Nr. 993. Pamatas: Isakymas Kariuomenei 1921 metu Nr. $18 \S 1$ ir 150 eilès Nr. $1121^{111}$.

3-iosios pèstininkų divizijos štabo viršininkas mjr. Jonas Gricius savo garbès ženklą Vyties Kryžių Nr. 989 atsièmė vienas iš pirmujų - 1921 $\mathrm{m}$. rugpjūčio $12 \mathrm{~d}$. gavęs telefonogramą ${ }^{112}$.

1922 m. kovo 30 d. raštu, tai buvo Vyties kryžiaus kavalierių sąrašas su 41 pavarde, $\mathfrak{i}$ Ūkio dalị kreipèsi Baltgudžių bataliono atstovas. Baltgudžių batalionas gavo 36 Vyties kryžius. Paaiškèjo, kad penkiems Vyties kryžiaus kavalieriams garbès ženklai buvo išduoti anksčiau ${ }^{113}$.

Daugiausia Vyties kryžių iš Ūkio dalies buvo išduota 1923 m. pavasari. Tada 1923 m. balandžio 30 d. 6-ojo pèstininkų Pilënų kunigaikščio Margio pulko kpt. Pilypas Ignatavičius atsièmė pirmosios rūšies Vyties kryžius (Nr. 1171-1209), skirtus 6-ojo pulko kariams už mūšius su lenkais 1923 m. vasario 12-14 d. neutraliojoje zonoje ${ }^{114}$

Pavieniai apdovanojimai buvo atsiimami ir vèliau. Aviacijos štabo vyr. ltn. T. Šakmanas 1923 m. rugpjūčio 8 d. gavo pirmosios rūšies 1-ojo laipsnio Vyties kryžius, skirtus kpt. S. Jakščiui (Nr. 1356) ir vyr. ltn. V Šenbergui (Nr. 1357). Tačiau 2-ojo laipsnio Vyties kryžius Nr. 91, skirtas vyr. ltn. J. Dobkevičiui nebuvo išduotas, tikriausiai jo dar nebuvo Ūkio dalyje ${ }^{115}$.

$1923 \mathrm{~m}$. spalio mènesi 7 Vyties kryžiai buvo išduoti ir 1-ajam pèsti-

${ }^{109}$ CVA F 929. Ap. 9. B. 354. L.51- 54

${ }^{110}$ CVA. F 929. Ap. 9. B. 354. L.66

${ }^{111}$ CVA. F 929. Ap. 9. B. 354. L. 19

112 CVA. F 929. Ap. 9. B. 354. L.34

${ }^{113}$ CVA. F 929. Ap. 9. B. 354. L. 102

${ }^{114}$ CVA. F 929. Ap. 9. B. 357. L. 8

${ }^{115}$ CVA. F 929. Ap. 9. B. 357. L. 18 
ninku didžiojo Lietuvos kunigaikščio Gedimino pulkui (Nr. 1216-1217, $1219-1223)^{116}$.

1919 m. rugsėjo 13 d. Prezidento įsakymu kariuomenès vadui generolui Silvestrui Žukauskui turejo būti išduoti pirmosios rūšies Vyties kryžiai: 1-ojo laipsnio Nr. 86 ir 2-ojo laipsnio Nr. $92^{117}$.

\section{IŠVADOS}

Kovų su bolševikais metu, pasižymëjusių karininku ir karių apdovanojimui, Laikinoji Lietuvos vyriausybè 1919 m. liepos 30 d. įsteigè Kryžių "Už Tèvynę". 1919 m. rugpjūčio 22 d. Valstybės Prezidento ịsakymu 1-ojo laipsnio kryžiumi "Už Tẻvynę" buvo apdovanota pirmieji 220 karių. Tarp apdovanotojų buvo ir 40 karininku. Labiausiai pasižymėję iš ju 3 karininkai buvo apdovanoti 2-ojo laipsnio kryžiumi "Už Tèvynę". Pasibaigus kovoms su bolševikais iki 1919 m. pabaigos 1-ojo laipsnio kryžiumi "Už Tèvynę" buvo apdovanota 96 karininkai, o 16 karininkų buvo apdovanoti 2-ojo laipsnio kryžiumi "Už Tẻvynę".

1919 m. lapkričio mènesį buvo nugalèti bermontininkai. Pirmasis karininkas apdovanotas 1-ojo laipsnio Kryžiumi "Už Tẻvynę" už narsumą ir pavyzdingą pareigu èjimą bermontininkų užimtoje teritorijoje buvo Šiaulių komendantas karininkas A. Birontas. Pasibaigus kovoms su bermontininkais 1-ojo laipsnio kryžiumi "Už Tẻvynę" buvo apdovanoti 9 karininkai, o 2-ojo laipsnio kryžiumi "Už Tèvynę" 4 karininkai. 1919 m. lapkričio 30 d. Prezidentas A. Smetona patvirtino naujos formos šešiu galu kryžių, bet paliko pavadinimą "Už Tèvynę". 1920 m. vasario 3 d. Prezidento issakymu apdovanojimas buvo pavadintas Vyties kryžiumi. Pasižymèjusių karių kovose su bermontininkais apdovanojimas buvo tęsiamas jau Vyties kryžiumi.

Vienas iš kritiškų atsikuriančios Lietuvos valstybès gyvenimo momentų buvo $1920 \mathrm{~m}$. vasario 21-23 d. Panemunès kareivių sukilimas Kaune. Už pasižymėjimą malšinant sukilèlius 1-ojo laipsnio Vyties kryžiumi apdovanoti 3 karininkai, o 2-ojo laipsnio Vyties kryžiumi 2 karininkai.

Nuo 1919 m. balandžio i Lietuvą nuolat brovèsi lenkų kariuomenè. 1920 m. rudeni atkaklios kovos vyko Suvalkijoje. Spalio 9 dieną želigovskininkai užgrobė Vilnių. Lenkai buvo sumušti Giedraičių ir Širvintų

\footnotetext{
${ }^{116}$ CVA. F 929. Ap. 9. B. 357. L.27

${ }^{117}$ Krašto apsaugos ministro isakymas Nr. 13. § 1. 1924 m. sausio 29 d.
} 
kautynėse. Kovu su lenkais metu ir joms pasibaigus einantis Respublikos Prezidento pareigas A. Stulginskis už pasižymèjimą mūšiuose 1-ojo laipsnio Vyties kryžiumi apdovanojo 61 karininką, o 2-ojo laipsnio Vyties kryžiumi 5 karininkus.

$1921 \mathrm{~m}$. pabaigoje lenkai nedidelėmis grupėmis pradëjo puldinèti Lietuvos sargybas neutraliojoje zonoje Širvintų-Giedraičių apylinkèse. Kaip atsakas nuo 1922 m. gegužès 1 d. iki 1923 m. birželio vidurio neutraliojoje zonoje veikè 4-ojo pèstininkų Lietuvos karaliaus Mindaugo pulko kariai partizanai. Už parodytą narsumą aštuoni leitenantai buvo apdovanoti Vyties kryžiumi. 1923 m. vasario 12-14 d. už pasižymëjimą ginant Valkininkų-Rūdiškių barą buvo apdovanoti Vyties kryžiumi šeši 6-ojo Menų pulko karininkai.

Pasibaigus nepriklausomybès kovoms krašto apsaugos ministro Balio Sližio ịsakymu 1923 m. gegužès 5 d. buvo sudaryta pirmoji Vyties kryžiaus ordino taryba, kuri parengè apdovanojimu pirmosios rūšies Vyties kryžiumi sąrašą. 1-ojo laipsnio Vyties kryžiumi buvo apdovanota 32 karininkai, o 2ojo laipsnio Vyties kryžiumi-5 karininkai. Jų tarpe už Klaipedos krašto išvadavimą 1-ojo laipsnio Vyties kryžiumi buvo apdovanoti 4 karininkai. Tai buvo paskutinis apdovanojimas pirmosios rūšies Vyties kryžiumi.

Mūšiuose su priešais žuvo 18 Lietuvos karininkų Vyties kryžiaus kavalieriu.

1920-1926 m. antrosios rūšies Vyties kryžiumi buvo apdovanojami karininkai už veiklą išaiškinant POW, už nuopelnus žvalgybos srityje, už kariuomenès aprūpinimą, už darbštumą atliekant pareigas. Pirmasis apdovanotas antrosios rūšies 1-ojo laipsnio Vyties kryžiumi buvo vyr. ltn. Vladas Gricius, o paskutinis antrosios rūšies 1-ojo laipsnio Vyties kryžiųmi apdovanotas 2-ojo pėstininku pulko mjr. V. Steponaitis. Daugiausia, net 33 karininkų antrosios rūšies 1-ojo laipsnio Vyties kryžiumi apdovanota 1926 m. birželio 7 d. Lietuvos Prezidento A. Stulginskio aktu.

Vyties kryžių ženklus gamino Karo invalidų komiteto graverių dirbtuvès. $1921 \mathrm{~m}$. rugpjūčio mènesi Krašto apsaugos ministerijos Tiekimų vadybos Ūkio dalis pradèjo kariniams daliniams tame tarpe ir karininkams išduoti pagamintus Vyties kryžius. 


\begin{abstract}
Résumé
Officiers chevaliers de l'ordre de la croix de Vytis, 1919-1926, Vincas

Ruzas.
\end{abstract}

(Musée national lituanien)

Le 30 juillet 1919 le gouvernement provisoire de la Lituanie a crée l'ordre de la croix « Pour la patrie » pour récompenser les officiers et les soldats qui se sont distingués au moment des combats contre les Bolcheviques. Sur ordre du président du gouvernement les 220 premiers soldats ont reêu la croix « Pour la patrie » premier grade le 22 août 1922. Parmi les décorés se trouvaient 40 officiers. Parmi eux, les trois officiers qui s'étaient le plus distingués ont reêu la croix « Pour la Patrie » deuxième grade. Une fois les combats contre les Bolcheviques terminés et d'ici la fin de l'année 1919, 96 officiers ont reêu la croix « Pour la Patrie », premier grade et 16 officiers ont reèu la croix « Pour la patrie » deuxième grade.

Les partisans de Bermontas ont été vaincus en novembre 1919. Le premier officier récompensé par la croix « Pour la patrie » premier grade pour sa bravoure et sa conduite exemplaire sur le territoire occupé par les partisans de Bermontas fut le commandant officier de Siauliai A. Birontas. Les combats contre les partisans de Bermontas achevés, 9 officiers ont été récompensés par la croix « Pour la patrie » premier grade et 4 officiers par la croix « Pour la patrie » deuxième grade. Le 30 novembre 1919 le président A. Smetona a confirmé la nouvelle forme de la croix, désormais ${ }^{\wedge}$ six branches. Son nom est resté le mzme « Pour la patrie ». Le 3 février 1920, sur ordre du président, cette décoration a été nommé croix de Vytis. Les soldats s'étant distingués lors des combats contre les partisans de Bermontas ont été désormais récompensés par la croix de Vytis.

Un des moments critiques dans la vie du gouvernement lituanien en pleine reconstruction a été le soulèvement des soldats de Panemune ${ }^{\wedge}$ Kaunas du 21 au 23 février 1920. Trois officiers ont été récompensés par la croix de Vytis premier grade et 2 officiers par la croix de Vytis deuxième grade pour s'ztre distingués lors de la répression du soulèvement.

Des le premier avril 1919, l'armée polonaise ne cessa de s'infiltrer sur le territoire lituanien. A l'automne 1920 des combats acharnés eurent 
lieu dans la région de Suwalki. Le 9 octobre les hommes de Zeligovski prirent Vilnius. Les Polonais ont été battus lors des batailles de Giedraiciai et de Sirvintos. Lors de combats contre les Polonais et une fois ceux-ci achevés, le président de la République lituanienne A. Stulginskis a décoré 61 officiers de la croix de Vytis premier grade et 5 officiers de la croix de Vytis deuxième grade pour s'ztre distingué pendant les combats. Vers la fin de l'année 1920, les Polonais par petites troupes commencèrent 3 attaquer les sentinelles lituaniennes dans la zone neutre des environs de Sirvintos-Giedraiciai. En guise de réponse les partisans soldats du régiment d'infanterie Mindaugas, roi de Lituanie sont entrés en action dans la zone neutre du $1^{\mathrm{er}}$ mai 1922 au 23 juin 1923. Pour leur bravoure 8 lieutenants ont été décorés de la croix de Vytis. Six officiers du sixième régiment de Pilenai ont été récompensés par la croix de Vytis pour s'ztre distingué lors de défense de ligne de front Valkininkai-Ru-diskiai du 12 au 14 février 1923.

Une fois les combats pour l'indépendance achevés, sur ordre du ministre de la Défense Balys Slizys, le conseil de l'ordre de la croix de Vytis, composé pour la première fois le 5 mai 1923, prépara la liste des décorations de l'ordre de la croix de Vytis première classe. Trentedeux officiers ont été décorés de la croix de Vytis premier grade et 5 officiers de la croix de Vytis deuxième grade. Quatre officiers ont été décorés de la croix de Vytis premier grade pour la libération de la région de Klaipe-da. Ce furent les dernières décorations de l'ordre de la croix de Vytis première classe. Dix-huit officiers lituaniens, chevaliers de la croix de Vytis moururent lors de combats contre les ennemis.

De 1920 q 1926 des officiers furent récompensés de le croix de Vytis deuxième classe pour leur action mettant q jour POW, pour leurs mérites dans le domaine de l'espionnage, pour l'approvisionnement de l'armée pour leur conduite exemplaire. La première personne décorée par la croix de Vytis deuxième classe premier grade fut le lieutenant en chef Vladas Gricius, et le dernier a été le major du deuxième régiment d'infanterie V. Steponaitis. Sur acte du président lituanien A. Stulginskis le plus grand nombre d'officiers, trente-trois, ont été décorés en mzme temps de la croix de Vytis deuxième classe premier grade le 7 juin 1926.

Les croix de Vytis sont fabriquées dans les ateliers de gravure du comité des invalides de guerre. En août 19211e département d'approvisionnement de ministcre de la Défense a commencé 3 distribuer les croix de Vytis aux unités de soldats et dans le mzme temps aux officiers. 